2010

\title{
Surveying History at the International Criminal Tribunal for the Former Yugoslavia
}

Richard Ashby Wilson

University of Connecticut - Storrs, richard.wilson@uconn.edu

Ahmad Wais Wardak

University of Connecticut - Storrs

Andrew Corin

Defense Language Institute

Follow this and additional works at: https://opencommons.uconn.edu/hri_papers

Part of the International and Area Studies Commons, and the Legal Studies Commons

\section{Recommended Citation}

Wilson, Richard Ashby; Wardak, Ahmad Wais; and Corin, Andrew, "Surveying History at the International Criminal Tribunal for the Former Yugoslavia" (2010). Research Papers. 6.

https://opencommons.uconn.edu/hri_papers/6 


\section{DRAFT}

"Surveying History at the International Criminal Tribunal for the Former Yugoslavia."

(C2010 Ahmad Wais Wardak, Andrew Corin, Richard Ashby Wilson
A Research Paper of the Human Rights Institute of the University of Connecticut 


\section{Author Biographies}

Andrew Corin is Associate Dean of Resident Education in the Directorate of Continuing Education of the Defense Language Institute. He is the author of one book and numerous articles on Slavic linguistics, textual analysis, and intensive foreign language instructional methodology. From 1999 through 2007, as a Research Officer with the Office of the Prosecutor of the ICTY, he analyzed expert submissions by prosecution and defense teams, articulated guidelines relevant to expertise, and himself authored multiple expert submissions and testified as an expert. In 2007, Prof. Corin was a Public Policy Scholar at the Woodrow Wilson International Center for Scholars. Email: arcrmc@att.net

Ahmad Wais Wardak is a Ph.D. Candidate of Political Science at the University of Connecticut. He completed a Master's degree in International Studies as a Fulbright scholar in 2007. Prior to this, Wardak was working as a National Program Officer for the United Nations Development Programme and UN-Office for Project Services (UNDP/UNOPS) in Kabul, Afghanistan. Previously, he was engaged with the Afghan NGOs in Pakistan that were involved in Land Mine clearance and awareness programs concerning the rights of persons with disability. In addition, Wais Wardak has been the co-founder of the Gorbat Cultural Organization and, for six years, served as the Editor of its bimonthly magazine, the Gorbat. Including numerous journalistic reports, he is the author of two academic journal articles, The Afghan Conflict: Foreign Intervention and Ideological Competition (2006), and The Application of Islam for Political Purposes in Afghanistan (2007).Email: Ahmad.Wardak@uconn.edu

Richard Ashby Wilson is the Gladstein Chair of Human Rights, professor of anthropology and law, and director of the Human Rights Institute at the University of Connecticut. He is the author or editor of numerous books and articles on human rights, truth commissions, and international criminal tribunals, including The Politics of Truth and Reconciliation in South Africa (2001), Human Rights in the "War on Terror" (2005) and Humanitarianism and Suffering: the mobilization of empathy (2009, co-edited with Richard D. Brown). His book Writing History in International Criminal Trials is forthcoming in the Law Series of Cambridge University Press. Email: Richard.Wilson@UConn.edu 
"Surveying History at the International Criminal Tribunal for the Former Yugoslavia."

\section{Introduction}

There now exists a large body of scholarship assessing international and national criminal trials for alleged mass violations of international humanitarian law. One debate in this literature evaluates the degree to which these trials have examined the origins and causes of violations, and provided an accurate historical record of the context of the crimes. By and large, historians and legal commentators are critical of law's ability to engage in historical inquiry. Liberal legalists have maintained that historical discussion of the underlying factors in a conflict defeats the ends of justice, understood as a fair hearing of the charges against one individual (Arendt 1965; Todorov 1996). Scholars from the law and society tradition have highlighted the distinctive characteristics of history and law, arguing that law and history are incompatible since they employ distinctive epistemological methods (Evans 2002; Rousso 2000; Sadkovich 2002); that law's own rules and procedures create a reductive template that actually distorts historical and social realities (Golsan 2000b); that law's minimal regard for context means it is inevitably partial with respect to the historical record (Geertz 1983; Bloxham 2001; Marrus 1997; Minow 1998; Mertus 2000) or that the courtroom is just plain boring in its excessive concern with meticulous procedural rectitude and therefore represents the wrong platform for revealing historical truths (Osiel 2000). A few countervailing views have emerged, and Lawrence Douglas (2001) has maintained that at Nuremberg newly minted legal categories propelled historical inquiry. By and large, though, the majority have formed a low opinion of law's capacity to conduct historical analysis.

With the recent emergence of an array of international criminal justice institutions including the International Criminal Tribunal for the former Yugoslavia (ICTY, established 1993), the International Criminal Tribunal for Rwanda (ICTR, 1994) and the International 
Criminal Court (ICC, 2002), new discussions have coalesced around the case law and jurisprudence of international criminal tribunals (Cassese 2003, Dörmann 2003, Schabas 2001, 2009), the international geo-politics of the Tribunals (Hazan 2004, Moghalu 2008, Peskin 2008), the impact (or lack thereof) of the Tribunals in the countries and regions concerned (Tosić 2007, Clarke 2009), and the effect of legal judgments on survivors of violence (Nettelfield 2010, Stover 2005). Accounts of the internal working of international courts have also started to be published, either in memoirs by key actors (Goldstone 2000, Del Ponte 2009) or in ethnographic studies by social scientists (Hagan 2003). As yet, there has been very little evaluation of the historical accounts of armed conflicts produced by contemporary international justice institutions, and what there is has tended to focus on the judgments written by judges at the end of cases (Donia 2004, Turković 2003, Wilson 2005, 2007).

While providing important insights on the place of historical evidence in published case law, these discussions can only infer conclusions about the relevance and weight given to historical evidence in reaching a judgment. Despite some excellent work in the early stages of the Tribunal (Hagan 2003), there is still precious little information on the international criminal legal proceedings as a dynamic decision-making process, and on the complex interactions between the strategies and understandings of the legal actors. As Jens Meierhenrich (2008:702) observes, while we have a solid grasp of the jurisprudential dimensions of international courts and tribunals, we know "close to nothing" about them as complex social institutions made up of different groups with a variety of goals and assumptions. To answer our questions about the relationship between international law and regional histories, what is needed is empirical research on how prosecutors and defense attorneys strategize in their use of historical evidence in the Trial Chamber, and what expert witnesses called by prosecution or defense hope to convey in their oral testimonies or written reports. This is the lacuna in the literature that this research seeks to fill. 
By surveying key actors in cases at the ICTY, the longest functioning ad hoc tribunal, about their intentions, motivations and perceptions, we might arrive at a greater understanding of their strategies and their assessment of the overall value and influence of historical testimony. Since the survey is anonymous, actors may be less constrained in expressing their own candid assessments than in public statements or interviews. Furthermore, while analysis of trial transcripts provides worthwhile information about how historical debates transpired in the Trial Chamber, by undertaking the discussion outside of the rough-and-tumble adversarial process of the courtroom, a more balanced evaluation might be forthcoming from the parties. Finally, in the survey format, respondents are not asked to tie their responses to a specific case, and this might permit them to base their answers on a more global assessment of the Tribunal's legacy since it began over 17 years and 161 indictments ago. As the Tribunal comes to the end of its term (probably in 2014), such "exit surveys" of former Tribunal staff and defense team members can comprise an integral part of the appraisal of the ICTY's work.

In order to augment what can be learned from case law and trial transcripts, and to furnish new insights into the perspective of legal actors with respect to the debate on legal histories of mass crimes, we turned to three categories of participants in the process - ICTY staff members, members of defense teams, and external expert consultants/witnesses-with the following three overarching themes in mind:

- Motivations: What do prosecutors and defense attorneys seek to achieve by including historical evidence in a case? How do they use such evidence to build their theory of a case? How do they understand the intentions of the opposing party? What relationship do they see between historical evidence and other aspects of the legal case and other forms of evidence? Are international trials more or less conducive than their national counterparts to admitting historical testimony?

- Courtroom Consequences: How is historical evidence received by the judges? How do judges decide between opposing views of history and are they perceived 
as tilting towards one party or the other in their deliberation? Is oral testimony more effective than written, and are defense and prosecution witnesses perceived to be equally well prepared?

- External Outcomes: Has the Tribunal provided an adequate account of the origins, causes and processes of conflict in the former Yugoslavia? Have historical discussions enhanced or undermined the Tribunal's legitimacy in the former Yugoslavia?

In designing a survey of former ICTY staff, defense team members and external expert consultants/witnesses on historical matters, we were attuned to areas where a consensus or strong divergences seemed likely. While we understand the ICTY to be a 'hybrid' international criminal tribunal that combines elements of Anglo-American criminal law and the Continental civil-law system, ICTY trials are still propelled by the adversarial process and as such, we were naturally interested in comparing the responses of persons working on the prosecution and defense side. Another potential fault line lies between lawyers and others working within the legal process, on the one hand, and "non-legal" participants such as expert witnesses, who are largely based in academic institutions, although experts are usually called by one of the contending parties, rather than as independent parties by the ICTY judges.

Before outlining the survey's methods, results and analysis, it is necessary to set out the legal framework under which historical expert witness testimony is admitted in the ICTY courtroom. Two features are worth noting here: that international criminal tribunals have adopted a lenient approach to admitting evidence that is more comparable to the civil-law system and in sharp contrast to Anglo-American common law; and second, that the ICTY's approach to historical evidence changed over time, requiring written as well as live testimonial submissions on historical matters. 
Expert witness testimony at the ICTY is governed by a number of related rules of the Rules of Procedure and Evidence", beginning with Rule 89(C): "A Chamber may admit any relevant evidence which it deems to have probative value," with the main grounds for exclusion being "if its probative value is substantially outweighed by the need to ensure a fair trial [Rule 89(D)]." Rule 94bis authorizes either party to tender an expert statement, after which time the other party has thirty days to indicate whether it wishes to cross-examine the witness, and whether it challenges the qualifications of the witness and the relevance of their report, in whole or in part.

Unlike in the common law tradition, international criminal courts operate without an explicit hearsay rule. As in civil-law courts, there is no concern that a jury might be misled since there is no jury, and it is assumed that ICTY judges are competent to distinguish between reliable and unreliable evidence. In Tadić, the ICTY Trial Chamber rejected a motion filed by defense counsel seeking to exclude hearsay evidence as a general rule, affirming that the judges are able "by virtue of their training and experience, to hear evidence in the context in which it has been obtained and accord it appropriate weight. Thereafter, judges determine the relevance, reliability, and probative value of the evidence relying upon the "context and character of the evidence in question." ${ }^{2}$ The Tribunal is guided in admitting hearsay evidence "by the truthfulness, voluntariness and trustworthiness of the evidence." ${ }^{3}$

Over time, the ICTY became more, not less, flexible in its rules admitting expert evidence, in part a result of the acute pressure on the Tribunal by the United Nations

\footnotetext{
${ }^{1}$ Rules of Procedure and Evidence (ICTY), UN Doc IT/32, adopted 11 Feb. 1994. At the time of writing, there have been 44 revisions to the RPE.

${ }^{2}$ Prosecutor v. Tadić, Decision on the Defense Motion on Hearsay. ICTY Case No. IT-94-1-T . 5 August 1996, cited in Blaskić §28.

3 Tadić $\$ 16$
} 
Security Council to shorten the length of trials. ${ }^{4}$ After 1998, a number of amendments to the Rules of Procedure and Evidence signaled a shift away from the common law adversarial model in the direction of the Continental civil-law system: Rule 92 bis and Rule 94bis permitted the submission of written statements by experts, and evidence could be admitted into a case without being led in the Trial Chamber and in the absence of cross-examination, although either adversarial party could object and request crossexamination. Together, Rule 92bis and Rule 94bis allowed prosecutors and defense attorneys to submit enormous quantities of scholarly reports, books and articles, as well as non-governmental organization reports, films and videos. The documentary basis of cases swelled to barely-manageable proportions during this period; for instance, in Kordić and Čerkez the prosecution tendered 2721 exhibits, with the defense submitting 1643 exhibits. $^{5}$

In 2002, the ICTY developed a "completion strategy" that subordinated the legal process to a strict principle of expeditiousness. ${ }^{6}$ The rise of what Máximo Langer (2005:835) terms the "managerial judging model" granted more authority to judges to manage their cases aggressively in the pre-trial and trial phases. Rule 65 ter requires prosecutors to file a witness list, a document list and a list of contested matters and admissions. Judges can select which witnesses to call and limit their testimony under rules 73bis and 73ter. Rule 90F\&G give judges control over witness cross-examination to "avoid needless consumption of time." Trial Chamber decisions reinforced increased judicial authority, for instance, the Kordić decision in October 2000 prohibiting the prosecution from leading any evidence on "peripheral and background issues" in its rebuttal of the

\footnotetext{
${ }^{4}$ ICTY Judge Patricia Wald (2001:549) wrote that the "new Rules sharply respond to the problem of lagging trials."

${ }^{5}$ Kordić and Čerkez (IT-95-14/2) Case Information Sheet http://www.un.org/icty/glance/kordic.htm Last accessed 10 August, 2009.
}

${ }^{6}$ Report on the Judicial Status of the International Criminal Tribunal for the Former Yugoslavia and the Prospects for Referring Certain Cases to National Courts, U.N. Doc S/2002/678 (2002). 
defense case. ${ }^{7}$ Judges thus gained the means to pare down cases drastically, and regularly ordered prosecutors to drop a specific number of indictments or cut their cases by an arbitrary number such as $25-30 \%{ }^{8}$ Defense attorneys embraced these changes, saying that prosecutors regularly over-indicted. When prosecutors protested, judges ruled that any time spent addressing an objection would be subtracted from the time allotted to the party making the objection. ${ }^{9}$

While on the one hand, judges gained ever greater powers to restrict expert witnesses' testimony and cross-examination, the new evidentiary regime allowed more latitude for the parties to tender background and historical evidence. In practice, what happened in any given ICTY trial depended on the nature of the case, the charges against the accused and the inclination of the judges on the bench. Overall, however, after 2002 prosecutors called background expert witnesses rather less than before, and in a more targeted fashion, favoring instead a more conventional crime-based approach. In the pre-trial phase, the judges became more interventionist, reducing the scope of prosecution cases and in particular, limiting expert witness testimony and historical discussions. Defense cases were usually handled with a lighter touch, and defense counsel continued to call extensive historical expert witnesses at the ICTY. In sum, the role and scope of historical inquiry has varied widely during the life of the Tribunal and its use by the legal parties has shifted from the prosecution in the earlier phases to the defense as the Tribunal nears completion.

\footnotetext{
${ }^{7}$ Mundis (2001:376)

${ }^{8}$ On 14 November 2006, the Trial Chamber reduced the time previously allotted to the prosecution in the Prlić case by more than a quarter. In a Decision on 21 November 2006, the prosecution was given until December 4th to reduce the scope of the indictment against Momčilo Perisić by "at least a third."

${ }^{9}$ See Prlić Trial Chamber Decision of 14 November, 2006.
} 
II. Methodology and the Survey Instrument

After the survey was developed, a preliminary version was reviewed by the Center for Survey Research and Analysis at the University of Connecticut. The modified version was tested on a focus group of six individuals who were former ICTY staff and consultant expert witnesses that were not included in the survey. The focus group encouraged us to define more fully certain terms such as "historian" and "historical evidence". We included a fuller definition in the survey preamble and on the Internet page linked to the survey, which explained the rationale for the research project.

The final survey questionnaire was divided into two parts. Part 1 elicited information about the background of respondents, the organ of the ICTY (including defense) with which the respondent was last associated, the form and length of the respondent's participation in the work of the ICTY, the nature of the respondent's professional activities at the time when s/he first became associated with the ICTY and the respondents' familiarity with the former Yugoslavia and criminal justice systems prior to that association. We chose not to request information regarding ethnic/national/religious affiliation in the Balkans; this would generally not apply to ICTY staff, and only to some defense attorneys and expert witnesses, and we judged that numbers of responses would be insufficient to support conclusions. The primary focus of this investigation was rather on comparisons among the parties to the legal process, and between legal and non-legal actors. Who are our respondents? The chart below indicates their occupational background before their association with the Tribunal: ${ }^{10}$

\footnotetext{
${ }^{10}$ Approximately $60 \%$ in the "Other" category properly belong in one of the Criminal Justice System categories, as a judge, prosecutor or defense attorney. The remainder included a military lawyer, a number of journalists and graduate students.
} 


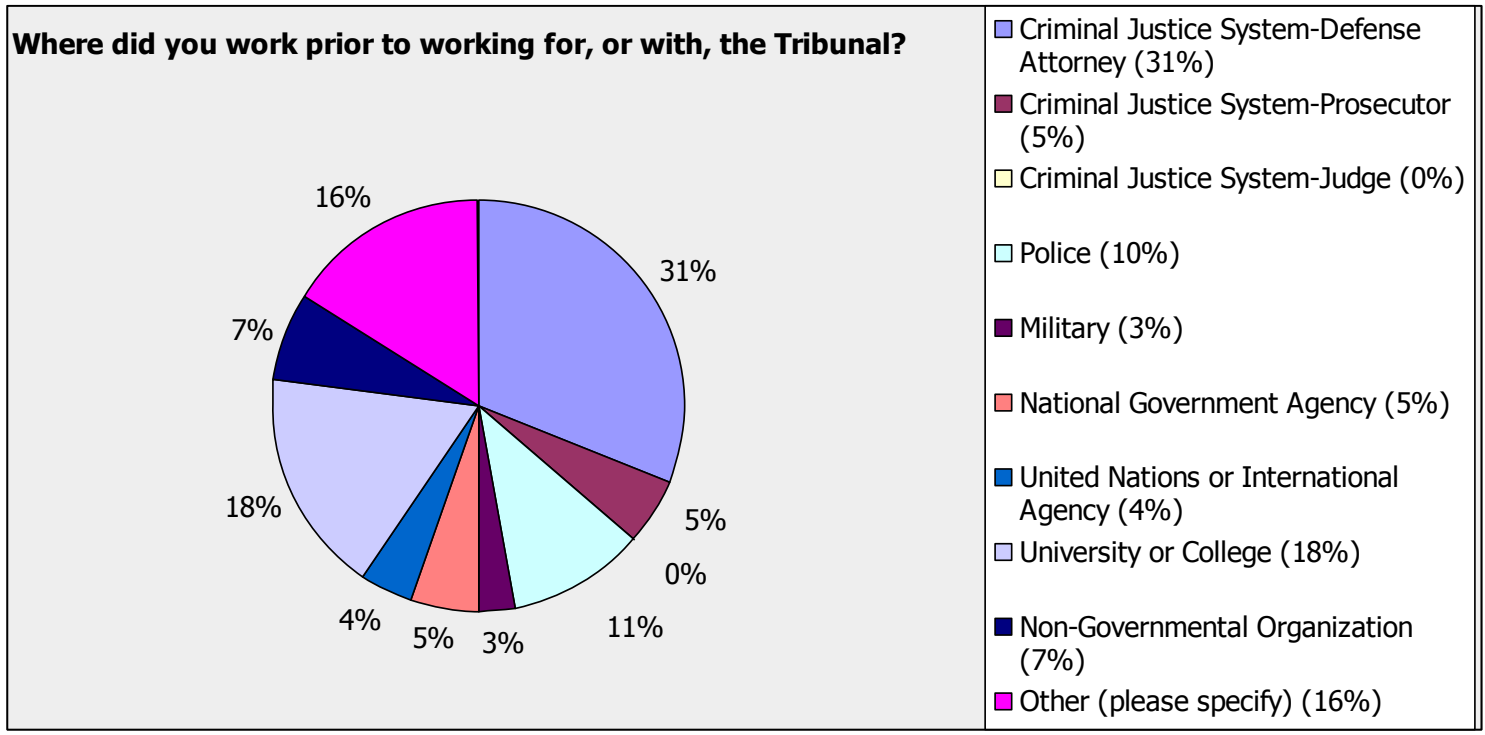

Figure 1

Part 2 covered the substantive issues addressed by the survey and was comprised of 36 questions grouped under 22 headings. The format varied between multiple choice (or multi-value) and true-false. This was done to avoid respondent fatigue and ensure that as many persons as possible would complete the survey. Although multiple choice (or multi-value) questions allow for more articulated results and the possibility for the "neutral" category to draw more responses, we judged that the benefit derived from varying the question format outweighed the limitations.

For most topics, we balanced questions related to the prosecution and the defense; if one question requested evaluation of evidence led by the prosecution, another would request an analogous evaluation of evidence led by the defense. This was done not only on grounds of objectivity, but also because we anticipated, in light of the ICTY's adversarial proceedings, that respondents' perceptions of the use of historical evidence in those proceedings might well vary in this dimension. The final open-ended question invited respondents to provide any comments that they chose. 
Considering the highly contested nature of the Tribunal's work and the adversarial character of its legal proceedings, we reflected on the ways in which we could ensure objectivity and neutrality. Thus, we acknowledged at least four distinct, albeit related, aspects of objectivity.

First, the disposition and background of the investigators. It should be noted that Andrew Corin was employed in the Leadership Research Team of the Office of the Prosecutor of the ICTY between June 1999 and January 2008. During that time, he actively assisted the prosecution through participation in basic research, focused investigations and trial preparation. He also participated as an author of expert reports and, on one occasion, as an expert witness.

Second, we also considered the relative independence of the investigators. Both Richard Wilson and Andrew Corin maintain professional and/or personal acquaintances with members of the ICTY staff and defense teams. Throughout this investigation, however, neither has had any affiliation with the ICTY or any other affiliation that would affect their neutrality.

A third issue relates particularly to fact-finding in adversarial situations, in which it is necessary to ensure that all perspectives and parties are sufficiently represented, corresponding to the legal principle of audi alteram partem. We sought to fulfill this requirement in designing the survey, defining the pool of prospective participants, and in soliciting and encouraging sufficient participation from all relevant groups of prospective participants.

Fourth, we sought to ensure that the appropriate spectrum of fields of expertise was consulted. In the direct investigation of war crimes and crimes against humanity, this is a necessary, albeit oft-overlooked, condition of objectivity. In the form of metainvestigation that we were carrying out, focused as it was on a particular topic, it might 
appear less relevant. However, we judged that it would qualitatively enhance the objectivity, and thus also the significance, of our results if we could achieve a balance of professional perspectives, both legal and non-legal, among our respondents. Similarly, it may also be noted that the fields of training and experience of the three investigators are largely complementary, and include both internal and external perspectives on the ICTY.

One limitation to the accessibility of the survey for prospective participants, and thus potentially impacting its objectivity, concerns language. While the use of English may have limited access for some potential respondents, it eliminated any possibility for ambiguous interpretation due to issues of translation. Moreover, as potential respondents were highly educated, we judged that the number of such persons lacking sufficient knowledge of English would be sufficiently limited so as not to overly skew the survey's results. For the final open-ended question, we invited respondents to provide their comments in one of several languages, including those of the former Yugoslavia.

Our greatest challenge arose in compiling the pool of potential participants and securing the participation of a sufficient number of respondents. We initially anticipated soliciting participation from all members of three groups: staff members of ICTY organs (Prosecutor, Chambers, Registry); defense team members; and external experts who participated in the ICTY's work through testimony, public-domain reports, or publicly known consultation for the prosecution or defense, including the defense for accused from various national/ethnic groups. Our goal was to obtain the broadest possible range of perspectives, both legal and non-legal.

Defining a desired pool of participants proved less challenging than securing the participation of a sufficient number of such persons. We hoped that the ICTY would assist us through the minimal step of informing staff members through e-mail of the existence of the survey. This would have ensured access for participants from across the 
spectrum of roles and perspectives represented in the various organs of the ICTY. The ICTY, however, declined to assist. To avoid any possibility of placing current staff members in a delicate position, or inadvertently to jeopardize the confidentiality of United Nations information, we ultimately chose to actively solicit the participation only of former Tribunal staff members. In the absence of any public domain lists of ICTY staff, present or former, we identified names and contact information of potential participants through personal recollections, published sources such as the domain ICTY Weekly Bulletins for the years 1996-2004, and searches of selected trial transcripts. These restrictions severely limited the pool of potential participants from the ranks of persons who had served as ICTY staff members. We were ultimately able to secure the participation of a sufficient number of erstwhile staff members from the Office of the Prosecutor. Responses from former staff members of the Registry and Chambers, however, were judged insufficient to allow for significant comparison, and we reluctantly excluded them from the analysis.

Securing the participation of defense team members proved less difficult. The Association of Defense Counsel maintains a public website with a list of names and contact information of members. This list, together with other information discovered through searching other public-domain sources, allowed us to contact a sufficient number of defense team members to allow for significant results. There exists no master list of external expert consultants, nor do there exist public-domain witness lists for most ICTY cases, so we found ourselves in much the same situation as in regard to ICTY staff members. We therefore applied the same methodology and rules to identifying these individuals. Finally, we published a call for participation on the survey website, directed to former ICTY staff members, members of defense teams, and expert consultants. In an attempt to achieve a sufficiently large and balanced set of responses we received a joint endorsement by both Richard Goldstone, the first Prosecutor of the ICTY, and Michael Karnavas, President of the Association of Defense Counsel Practicing 
Before the ICTY. We published this endorsement on the survey Internet page and included it in the prenotification letter that was sent to prospective participants.

In total, 351 email invitations to participate in the survey were sent out. The largest group approached were members of defense teams (201). Another 116 invitations were sent to former ICTY staff from the Office of the Prosecutor, Registry and Chambers. Finally, we invited 34 consultant experts for the prosecution and defense, most from academic institutions in North America and Europe, including the former Yugoslavia. The total number of responses collected was 75 , indicating a response rate of $21 \%$. Six incomplete responses were excluded from the analysis, leaving 69 responses. hat final figure was used to calculate a margin of error of $12 \% .{ }^{11}$

There was an approximate parity in responses between members of defense teams (25) and staff from the Office of the Prosecutor (31). Responses from external expert consultants (13), although a smaller population, were judged sufficient for inclusion in the analysis. Responses from staff of the Chambers and Registry were insufficient to support conclusions, and these categories were excluded from our analysis of the results. While recognizing that these numbers are relatively small, we hope that they may nevertheless be sufficiently indicative to initiate a scholarly discussion on the uses of historical evidence at the ICTY and other international criminal tribunals, and might serve as a pilot study for future large-sample surveys. We decided to report our results in percentages rather than raw numbers so as to facilitate comparison between the

\footnotetext{
${ }^{11}$ We calculated Margin of Error (MOE) based on a confidence level of $95 \%(\alpha=0.05)$, determined as follows: we estimate that the total population of our participants is less than 10,000 , but we used a conservative figure of 20,000 for our estimates. We assume the response distribution to be normal for the data we have collected. Using $\mathrm{N}=69$, based upon our analysis, we find the margin of error to be $11.5 \%$. In order to be conservative regarding our inferences, we use a MOE of $12 \%$ in this study.
} 
three main respondent groups-prosecutors, defense attorneys and expert witnesses for the defense and prosecution.

III. What is the Legal Relevance of Historical Evidence?

This section reviews those survey questions directed towards the specifically legal motivations for introducing historical evidence in a trial. In assessing the legal rationales for historical inquiry, we begin with the observation that there is no mandate to document the prior history of an armed conflict anywhere in the two UN Resolutions that established the ICTY in 1993. Therefore prosecutors and defense attorneys are not compelled by a formal mandate to write history, nor should we assume that they are necessarily committed to the inherent value of historical reflection for its own sake. However, all have an interest in advancing the most persuasive legal argument possible and the question becomes whether historical evidence is seen as assisting them in achieving that goal.

Our most general survey question on the relevance of history in international criminal trials asked survey participants to respond to the statement: "Without historical context, individual criminal acts do not appear to make sense." A majority of respondents (63\%) either agreed or strongly agreed, $27 \%$ disagreed or strongly disagreed, $9 \%$ were neutral and $1 \%$ expressed no opinion. Disaggregating the figures revealed that prosecutors and defense counsel were equally convinced of the relevance of historical context, and they agreed or strongly agreed with the statement at a rate of $61 \%$ and $60 \%$ respectively. These figures indicate a relatively high commitment among ICTY legal actors to using historical context to understand alleged crimes. Furthermore, historical evidence is valued equally by all parties in international criminal trials. 
Widespread consensus between the parties also existed on the question of the type of criminal trial that is more likely to include historical evidence.

Which type of criminal trial is more likely to include historical evidence?

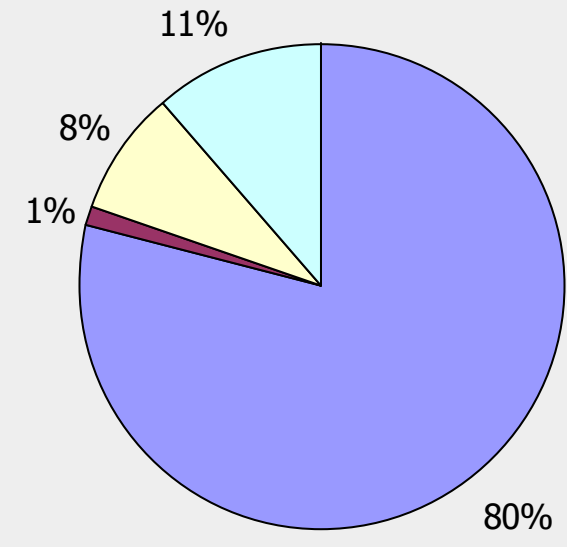

$\square$ International Criminal Tribunals $80 \%$

$\square$ Domestic trials in national justice systems $1 \%$

$\square$ International and domestic trials are about the same in this regard $8 \%$

$\square$ No opinion $11 \%$

Figure 2

This invites the question-what specific features of international criminal legal proceedings demand more historical evidence? We formulated a list of survey questions addressing the nature of the crimes committed during the armed conflict in the former Yugoslavia that compelled historical inquiry (e.g., their complexity or widespread character), and/or whether the need arose more from legal imperatives resulting from the categories of war crimes, crimes against humanity and genocide. ICTY legal actors agreed that the character of the crimes had a strong impact on the use of historical evidence and moreover, there were no sharp disagreements between defense counsel and prosecutors, whose responses were within 5-7\% of one another. 


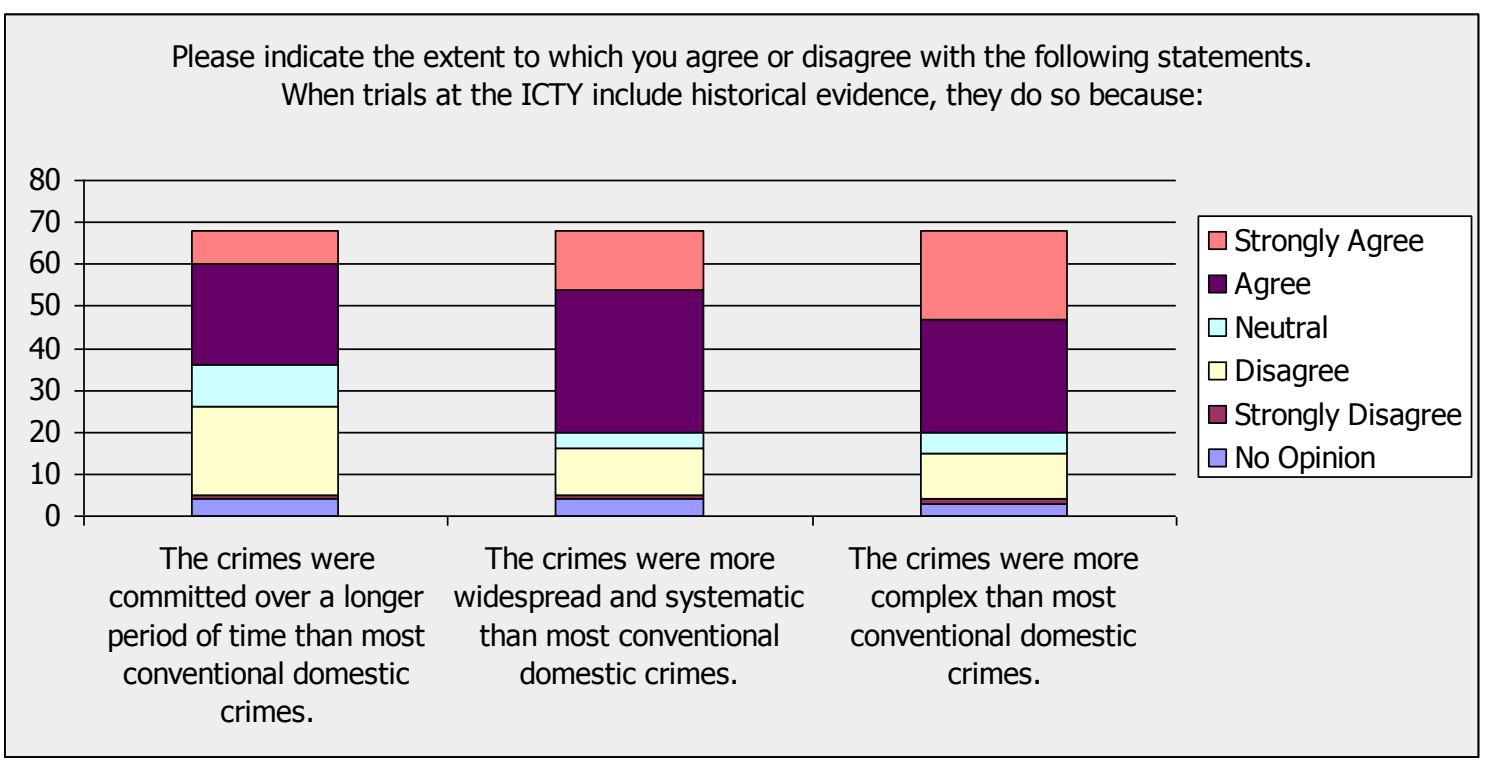

Figure 3

However, some strong divisions on the significance of historical elements of the Balkans conflict emerged. One highly controversial debate during the conflict and in the ICTY's trials concerned the degree to which the alleged crimes were motivated by deep historical animosities.

When trials at the ICTY include historical evidence, they do so because the crimes committed were motivated by deep historical animosities.

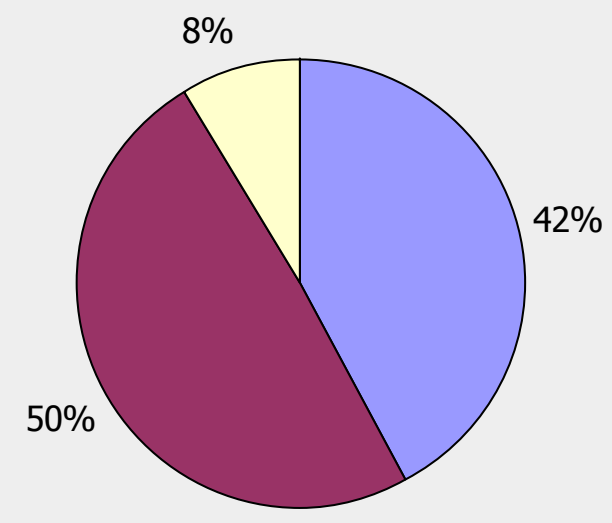


Unlike the questions considered thus far, no clear majority view was established. Intriguingly, prosecution and defense team members did not diverge widely in their responses, agreeing with the question at a similar level ( $51 \%$ and $46 \%$ respectively). Experts (both the prosecution and defense) overwhelmingly (77\%) rejected the "deep historical animosities" explanation of the conflict. It appears that in the minds of ICTY actors, the intrinsic attributes of the crimes brought before the ICTY - their complexity, their widespread and systematic nature, but not their motivation by a longstanding animus-impelled the Tribunal to consider their historical underpinnings. Our preferred explanation/conjecture is that the ambivalence regarding the relevance of "deep historical animosities" results from the mixed consequences for criminal responsibility in leadership cases. If the crimes drew from adamantine antipathies, then the prosecution could argue that the crimes were foreseeable, intensifying the culpability of leaders that made inflammatory speeches or armed their supporters. On the other hand, historical inter-group hatred could support a "chaos defense" whereby leaders were unable to restrain spontaneous violence that erupted at the grassroots. Both positions have been extensively argued by both parties in cases heard at the ICTY. ${ }^{12}$

Turning now to how historical evidence is shaped by the legal requirements contained within the categories of international criminal law, the pictured is more mixed than with explanations that refer to the nature of the crimes as considered above. A significant majority of participants saw a correlation between the inclusion of historical evidence and the collective dimensions of criminal categories such as genocide and persecution.

\footnotetext{
${ }^{12}$ A chaos defense has been a feature in numerous trials of political leaders including Radoslav Brđanin, Momčilo Krajisnik, Mićo Stanišić and Stojan Župljanin. The foreseeable consequences of actions is a prominent feature of the prosecution indictment against Bosnian Serb leader Radovan Karadžić presently appearing in the trial chamber. The Prosecutor v. Radovan Karadžić. Prosecution's Marked-Up Indictment. With Appendix A. Case IT-95-5/18-PT. 19 October 2009. e.g., §10, §39, §43, §50, §59.
} 
Prosecutors (77\%) were more likely to endorse the view than defense attorneys (60\%).

Expert witnesses showed least support for specifically legal explanations, with only a slender majority (53\%) in favor.

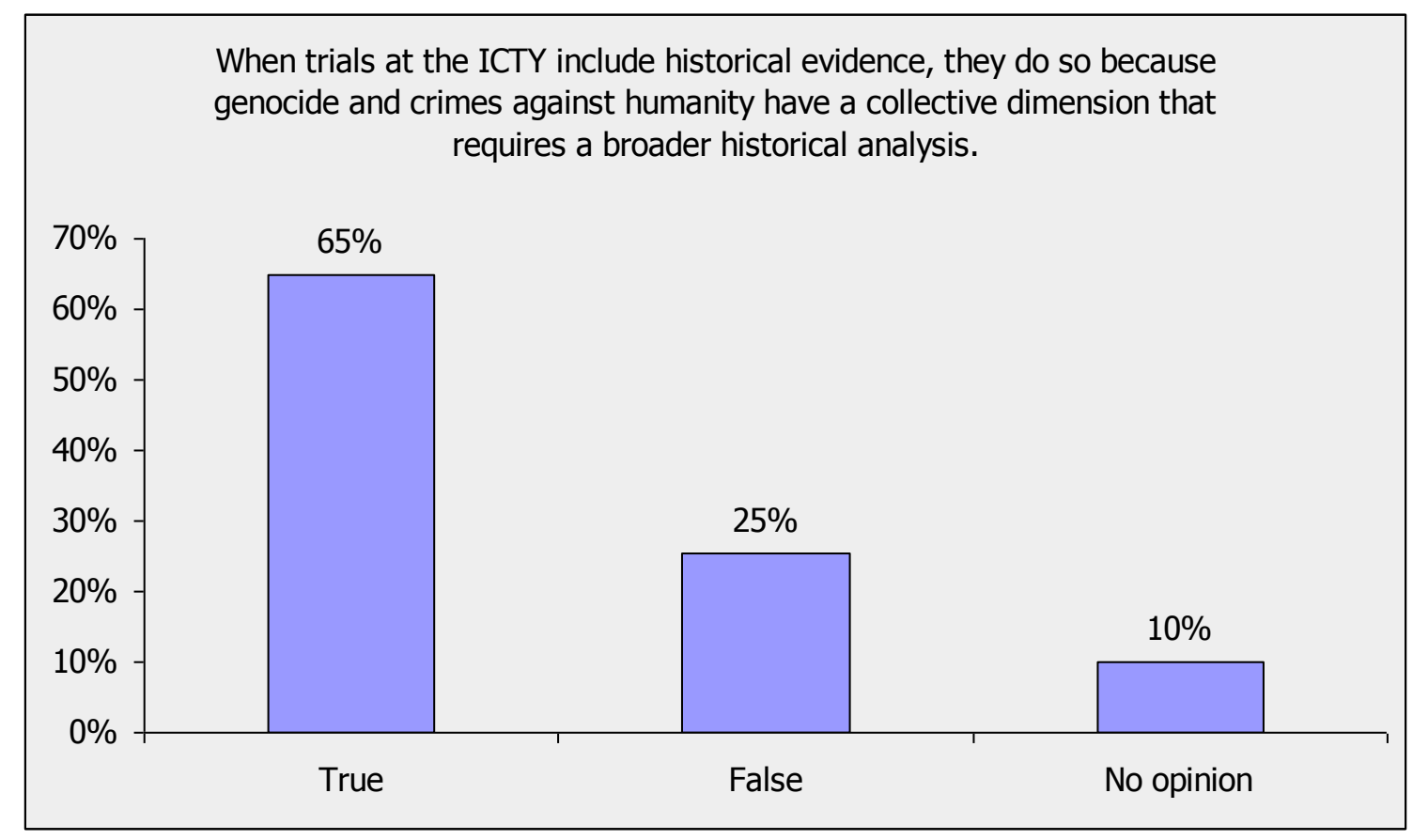

Figure 5

One unique dimension of international tribunals compared with national justice systems is that none of the judges are from the countries where the crimes were committed. A majority (58\%) agreed or strongly agreed with the statement: "Prosecutors lead historical evidence in the Trial Chamber to give judges a sense of the motivation for the crimes." $25 \%$ disagreed or strongly disagreed, $14 \%$ took a neutral position and $3 \%$ gave no opinion. Disaggregating the figures revealed a divergence between the prosecution and expert witnesses on the one hand and the defense on the other: $73 \%$ of prosecutors and $69 \%$ of expert witnesses agreed or strongly agreed with the statement versus only $28 \%$ of defense attorneys. One prosecution expert witness reflected at the end of the survey, "While those testifying as expert witnesses...come to their task equipped with a body of knowledge about the region, its history, language and cultures, the judges and those lawyers...in most cases begin their work at the tribunal almost totally uneducated 
on these matters. From remarks heard in court and encountered in written submissions and judgments, one gets the impression that some of the judges and lawyers may still be shaky in their grasp of basic facts and background information, even after having served on more than one case at the ICTY."

A number of questions focused on each of the parties to ICTY trials and their specialized strategies for using historical evidence. We felt this to be necessary since, even though historical expert witnesses may strive for objectivity and neutrality, they are after all included in the process to further the line of argument of one party or the other. ${ }^{13}$ Stated plainly, their very presence is a function of the adversarial process of the international criminal trial, and this may influence the scope and rationale of the historical evidence introduced. Indeed the survey did turn up assertions of distortion, bias and cynical misuse of historical evidence in the ICTY Trial Chamber. One prosecution respondent wrote, "Under the adversarial system, trial lawyers prefer a version of history that supports their case (they are not looking for objective (?) truth).... There is a tendency to produce 'cooked history'." Defense respondents seemed particularly aggrieved: "Testimony by 'historians' in many, if not all, of these trials, has been used itself to manipulate and mold the view of which ethnic group is bad, according to which ethnic group has been the victim. There is no consistency. If the Muslims are the victims, then the history is manipulated to show that either the Serbs or the Croats are the bad guys from an historical perspective, and vice versa."

Seeking to comprehend prosecutors' specific reasons for engaging historical expert witnesses, the survey asked about the degree have prosecutors used historical evidence in the Trial Chamber to assist in creating their theory of the case, where the theory is the "particular line of reasoning ...(that brings) together certain facts of the case in a logical sequence and correlates them in a way that produces in the decision-maker's

\footnotetext{
${ }^{13}$ Unless called as expert witnesses by the judges, which seldom occurs.
} 
mind a definite result or conclusion favored by the advocate." ${ }^{14}$ In plainer terms, the theory is the overarching story that integrates the "what happened" with the "why it happened" - the motives behind what happened.

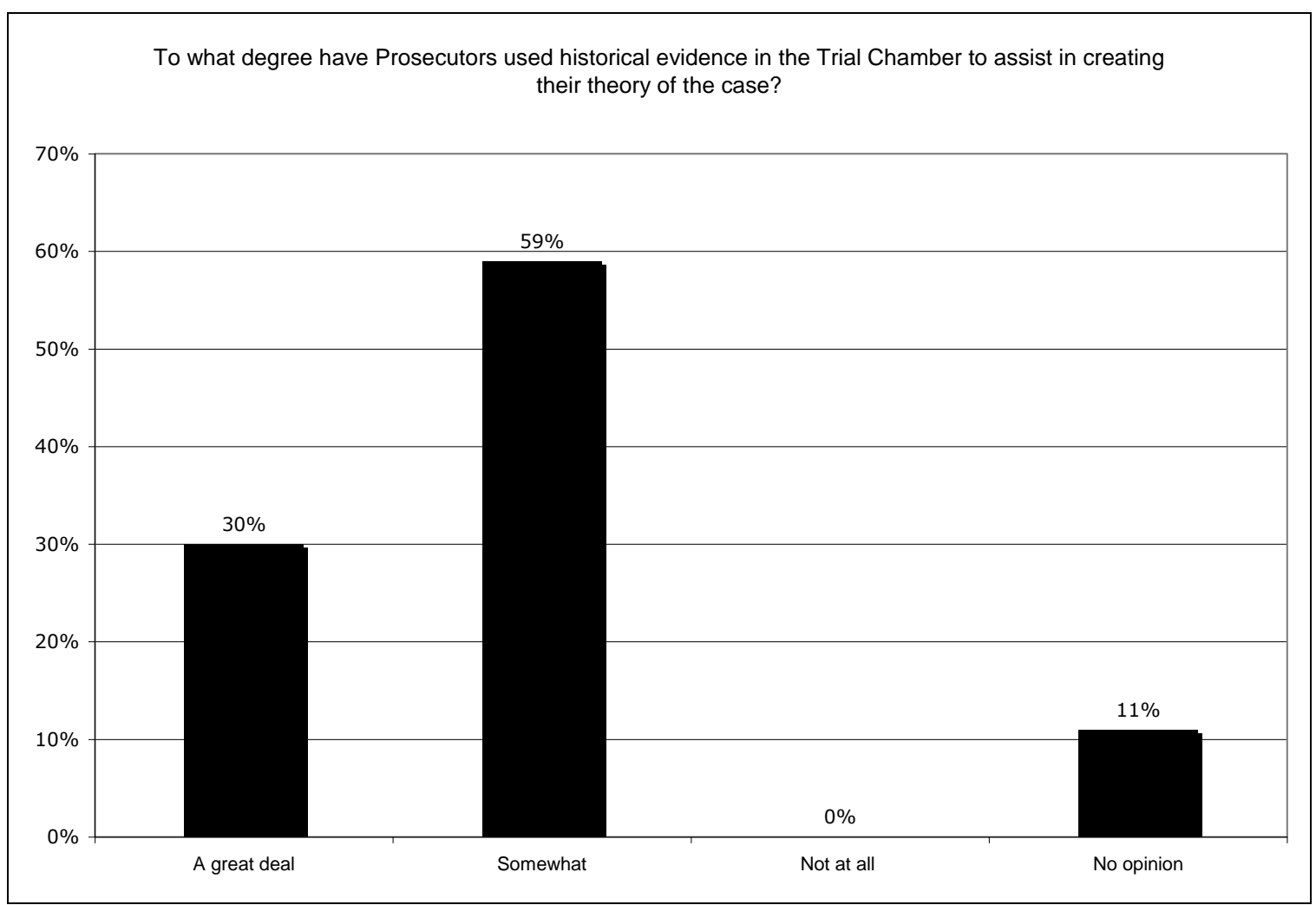

Figure 6

What particular aspects of the prosecution's theory of case are being enhanced? When presented with the statement "Prosecutors lead historical evidence in the Trial Chamber in order to give a sense of the motivation for the crimes," $57 \%$ agreed or strongly agreed, $14 \%$ were neutral and $24 \%$ disagreed or strongly disagreed, with $3 \%$ expressing no opinion. When disaggregated, these figures show a more variegated picture, with $74 \%$ of respondents from the Office of the Prosecutor and $69 \%$ of expert witnesses (both prosecution and defense) either agreeing or strongly agreeing. Only $28 \%$ of defense attorneys agreed and $0 \%$ expressed strong agreement. Therefore we can

${ }^{14}$ Black's Legal Dictionary 2006. 
conclude that for a sizeable majority of prosecutors surveyed, historical evidence speaks to the mental state of the accused, known as mens rea in criminal law.

Reviewing numerous ICTY trial judgments, it is apparent that prosecutors are more likely to turn to historical evidence to illustrate the mental state of the accused when genocide is charged. There are specifically legal reasons for this, as proving genocide requires the prosecution to demonstrate "special" or "specific" intent, defined as "a particular state of mind or a specific intent with respect to the overall consequence of the prohibited act."15 ICTY prosecutors have struggled to prove special intent to commit genocide. In 2010, 17 years after the ICTY was founded, there is still no standing conviction for committing genocide in the former Yugoslavia upheld on appeal. In cases such as Blagojević, Brđanin, Krstić and Krajišnik, Trial or Appeals Chamber judges found that the prosecution had not demonstrated the requisite level of special intent on the part of the accused. Special intent to commit genocide goes well beyond the standard intent of most domestic criminal trials and, to use a phrase coined by Trial Chamber judges in Stakić, prosecutors must demonstrate a "surplus of intent." ${ }^{16}$ In our view, this constitutes one of the main reasons why judges did not uphold full-liability genocide convictions. ${ }^{17}$ However, in June 2010 Bosnian Serb Army leaders Vujadin Popović and Ljubiša Beara were found guilty of committing genocide at Srebrenica and Žepa in eastern Bosnia, although this has yet to be upheld by the Appeals Chamber. ${ }^{18}$ One survey question directly addressed criminal intent, asking: "Is historical evidence

\footnotetext{
${ }^{15}$ Krstić (Trial Chamber), §571.

${ }^{16}$ Prosecutor v. Milomir Stakić, Case No. IT-97-24-T, Trial Chamber Judgment, 31 July 2003. $\S 520$.

${ }^{17}$ We accept there are also other reasons, including the prosecution case against defendants appearing before the Tribunal and the available evidence presented thus far. For an account of several cases where the charge of genocide was rejected at the ICTY, see Hayden (2008).

${ }^{18}$ Prosecutor v. Vujadin Popović et al. (Case IT-05-88) Trial Chamber Judgment, IT-05-88-T, 10 June 2010.
} 
relevant for proving mens rea in genocide cases; i.e., demonstrating that a perpetrator was aware of a wider policy or plan to destroy a group in whole or in part?"19 Our expectation was that there would be a strong division between prosecutors sanctioning this statement and defense attorneys categorically opposing it, as occurred above in the question on motivation for crimes. Instead there was a statistically significant consensus.

Is historical evidence relevant for proving mens rea in genocide cases; i.e., demonstrating that a perpetrator was aware of a wider policy or plan to destroy a group in whole or in part? (All respondents)

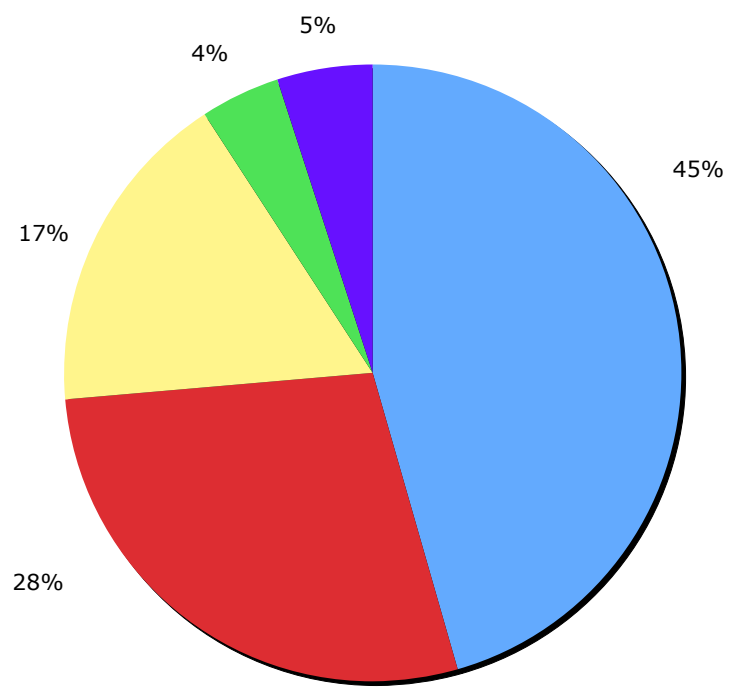

- Highly relevant $(45 \%)$ - Somewhat relevant $(28 \%)$ Somewhat irrelevant (17\%) - Highly irrelevant $(4 \%)$ No opinion (5\%)

Figure 7

Breaking these figures down further showed that respondents from the Office of the Prosecutor were more inclined towards viewing historical evidence as highly or somewhat relevant for special intent, but not by an overwhelming margin over defense counsel or expert witnesses.

${ }^{19}$ We neglected to add the words "as such", as included in the official Genocide Convention. While we regret this error, we do not feel that the omission influenced the responses greatly. 


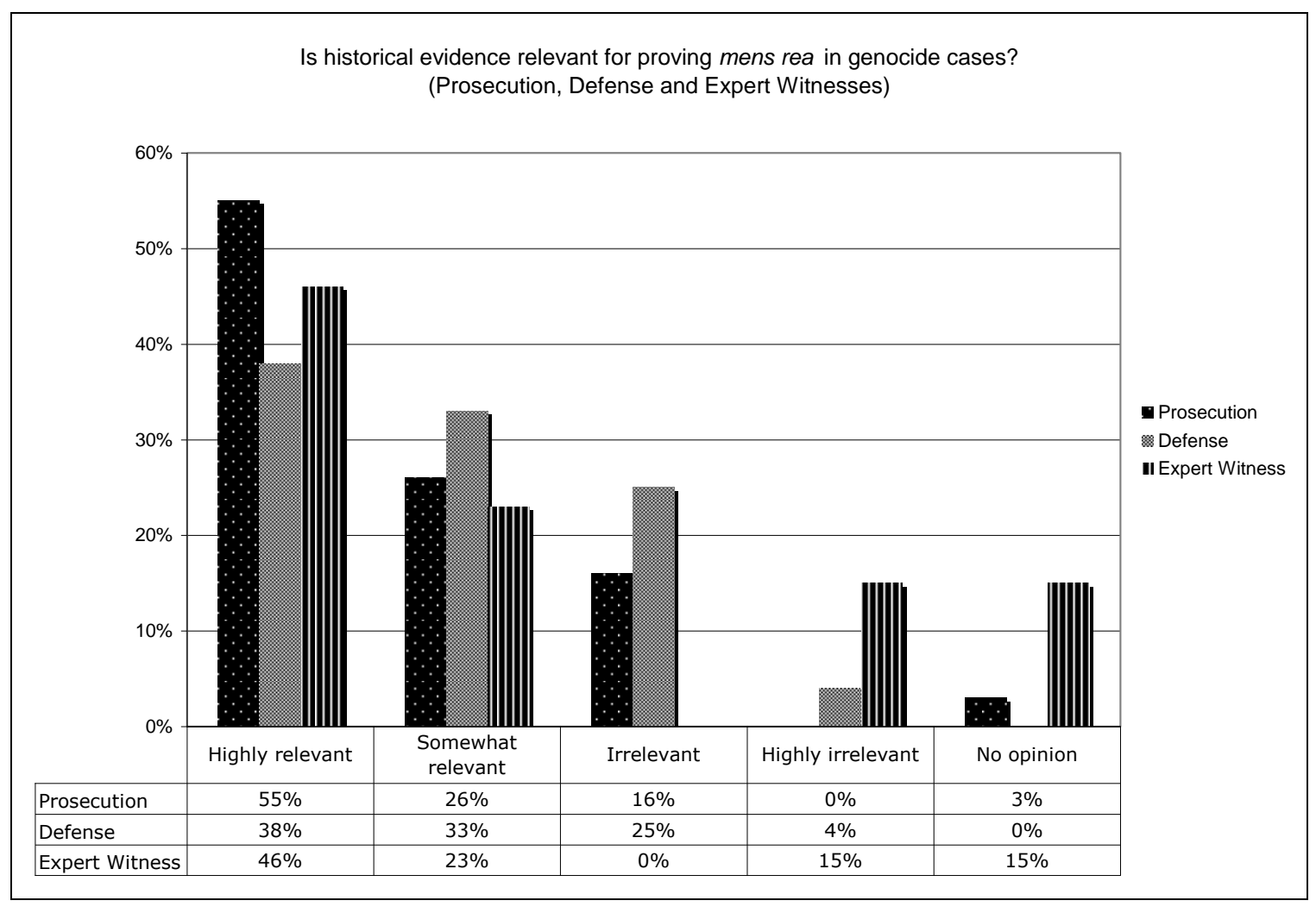

Figure 8

Conceivably as a result of Trial Chamber judgments such as Tadić and the Rule 98bis decision in Slobodan Milošević that confirmed the relevance of historical evidence to proving intent to commit crimes against humanity and genocide, this view has now become widely acknowledged. Yet why do defense respondents surveyed see a link between history and special intent, given their willingness to object energetically to aspects of Tribunal jurisprudence? We offer some thoughts on this question in our conclusions.

\section{Assessing the Outcomes of Historical Evidence}

In this section we review responses that assess the historical expertise presented at the ICTY, the Tribunal's attitude toward such evidence, and the Tribunal's utilization of that 
evidence. Although the quantifiable survey approach limited the research team to a small number of questions with closed answer sets, the final question invited respondents to add prose comments of unlimited length, which we will summarize at the conclusion of this section.

One series of questions elicited opinions concerning the contribution of experts toward the creation of a historical record of the conflicts and their historical context.

"In their testimony to the ICTY, historians have provided important information on..."

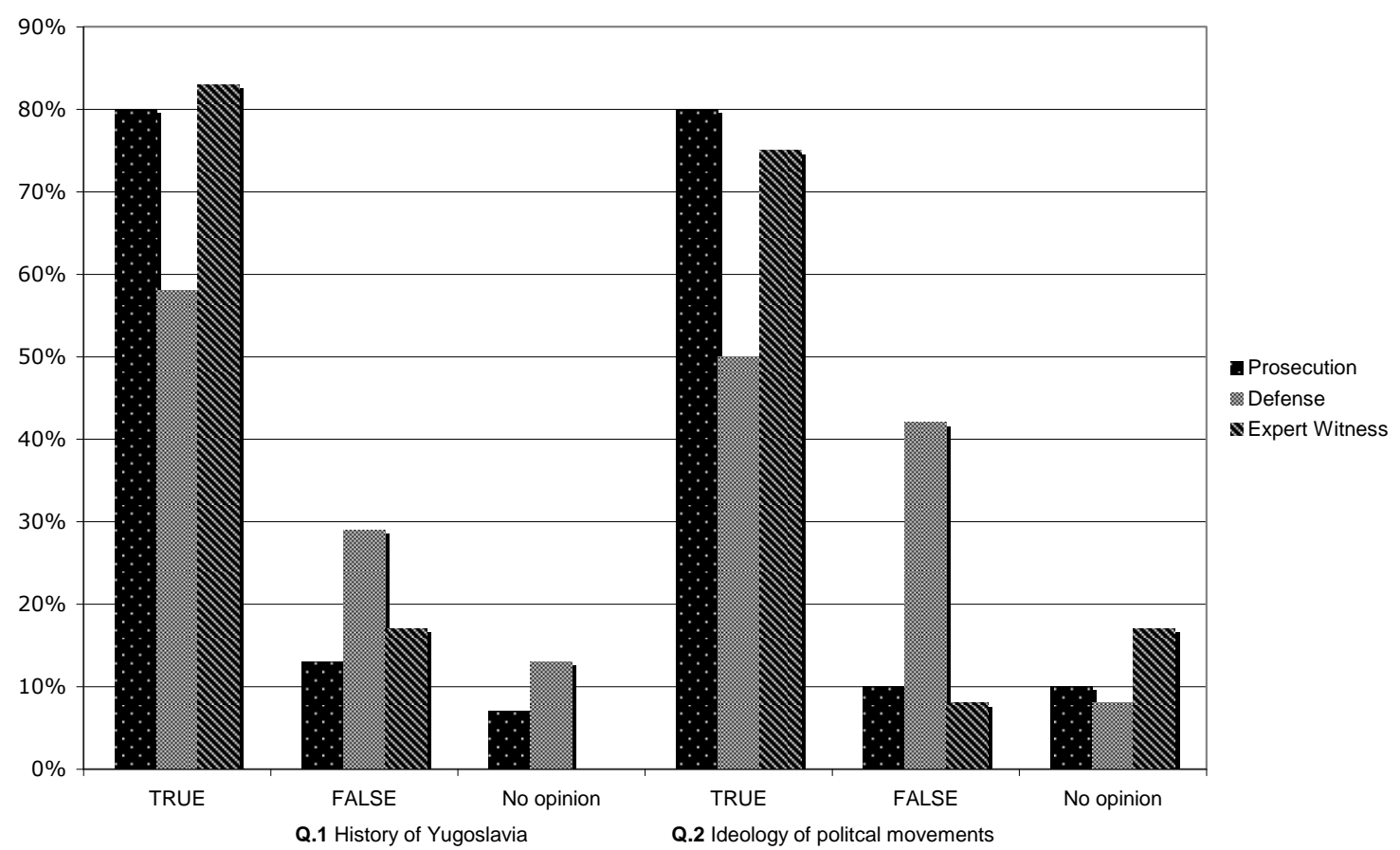

Figure 9a 
"In their reports and testimony to the ICTY, historians have provided important information on..."

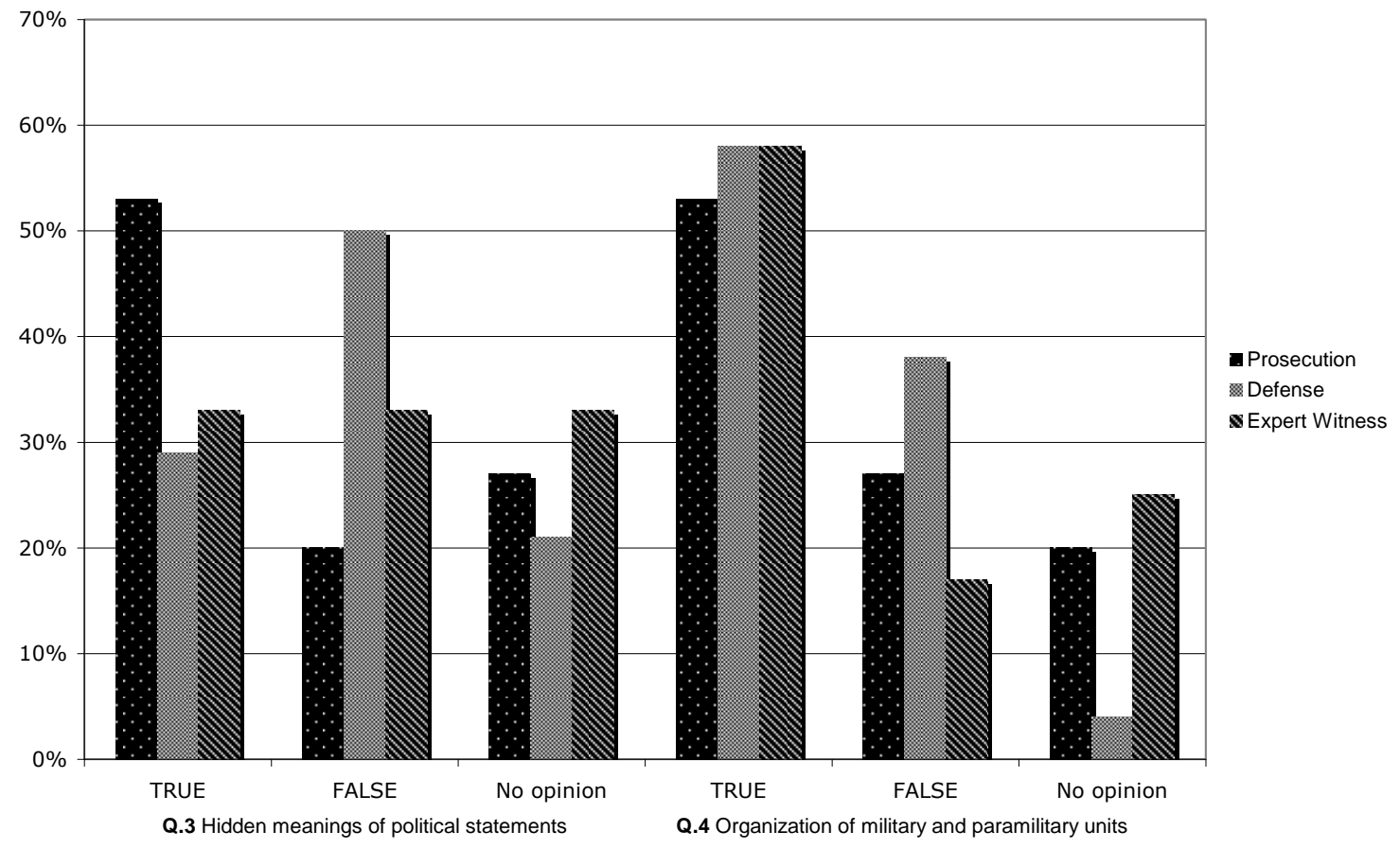

Figure 9b 
"In their testimony to the ICTY, historians have provided important information on..."

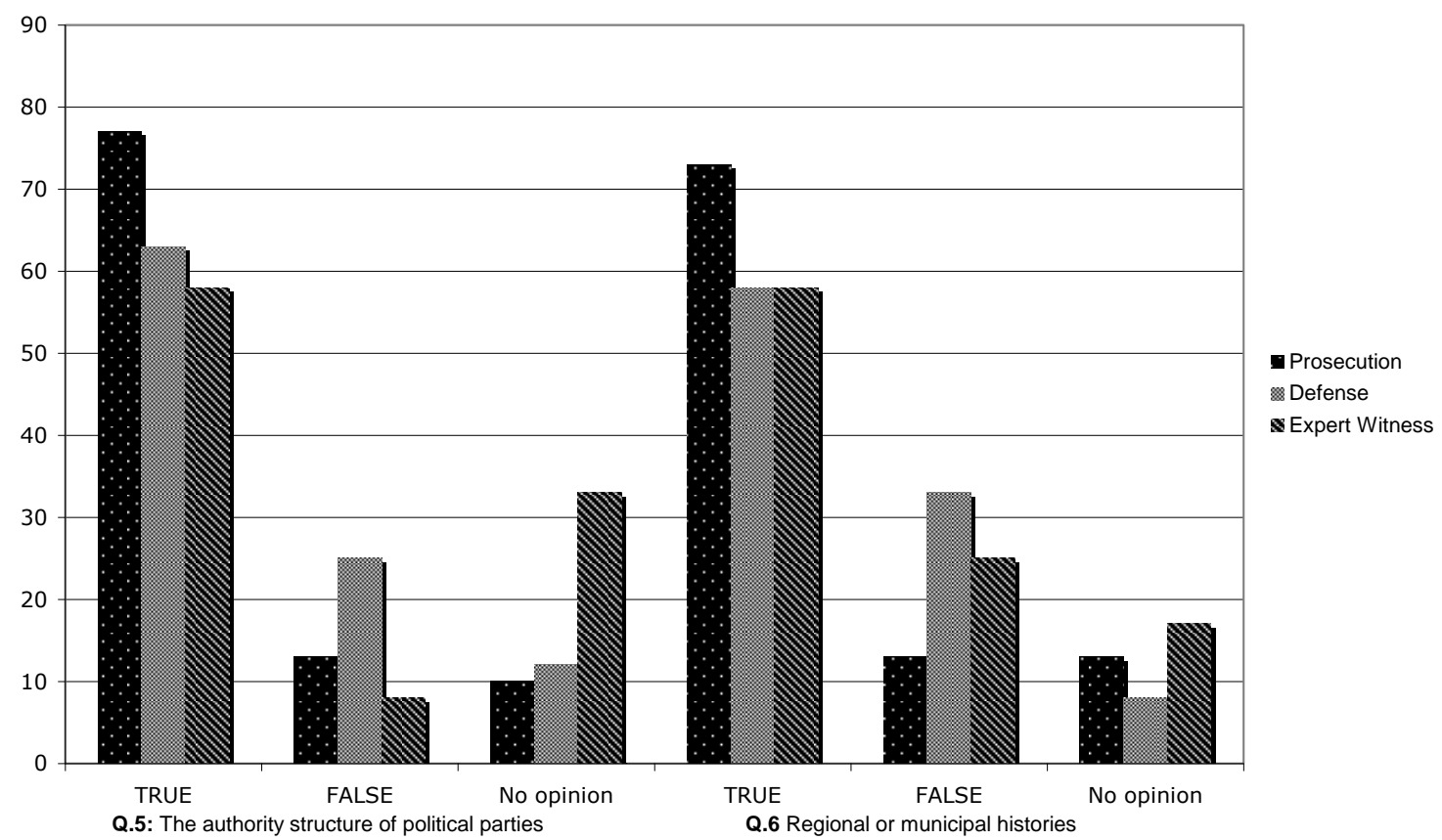

Figure 9c

Prosecution, defense and expert respondents tended to agree with these statements, but with two significant limitations. First, for each question, a larger proportion of prosecution respondents than defense respondents agreed. Second, the extent to which prosecution and defense respondents diverged depended on the degree to which the questions might relate to the responsibility for inciting conflict and the crimes against humanity. In response to the most general historical questions $(1,6)$, as well as factual questions about the parties to the conflict without reference to ideology or intent $(4,5)$, respondents tended to agree. Regarding the history and ideology of political movements (2), agreement between prosecution and defense diminished. Prosecution and expert respondents significantly agreed, while defense responses were more evenly split. On the one question that went directly to the intent of political leaders (3), prosecution and defense responses diverged widely. 
A second group of questions assessed the contribution of the parties in the ICTY processes. First we will consider trial chamber judgments, bearing in mind that the evidence provided by historical experts represents just one aspect of that available to judges in rendering conclusions of a historiographic nature. The most general evaluation of the historical aspect of the trial chambers' accounts was elicited by asking respondents to react to the statement: "In its judgments, the ICTY has produced an accurate and comprehensive account of the armed conflicts of the 1990's in the former Yugoslavia." The responses revealed a profound disagreement between defense and prosecution respondents:

\begin{tabular}{|l|c|c|c|}
\hline & Pros.\% & Defense\% & Witness\% \\
\hline Strongly Agree & 13 & 0 & 23 \\
\hline Agree & 48 & 16 & 38 \\
\hline Neutral & 23 & 16 & 8 \\
\hline Disagree & 10 & 48 & 15 \\
\hline Strongly Disagree & 6 & 16 & 15 \\
\hline
\end{tabular}

Figure 10

A second question sought confirmation of a more limited claim: "In its judgments, the ICTY has given important insights into the origins and causes of the armed conflict in the former Yugoslavia". Although respondents were generally more willing to acknowledge the validity of this claim, disagreement remains striking: 


\begin{tabular}{|l|c|c|c|}
\hline & Pros.\% & Defense\% & Witness\% \\
\hline Strongly Agree & 35 & 0 & 15 \\
\hline Agree & 42 & 32 & 46 \\
\hline Neutral & 16 & 12 & 0 \\
\hline Disagree & 3 & 20 & 23 \\
\hline Strongly Disagree & 3 & 28 & 8 \\
\hline No Opinion & 0 & 0 & 8 \\
\hline
\end{tabular}

Figure 11

Now we consider the historical expert evidence brought by the prosecution and defense. Two questions sought overall assessments of these contributions: "Historical evidence led by the prosecution/defense has provided important insights into violations of international humanitarian law in the former Yugoslavia."

\begin{tabular}{|c|c|c|c|c|}
\hline & & Pros.\% & Defense\% & Witness\% \\
\hline \multirow{6}{*}{$\begin{array}{l}\text { (1) Evidence led by the } \\
\text { prosecution }\end{array}$} & Strongly Agree & 55 & 4 & 31 \\
\hline & Agree & 26 & 20 & 23 \\
\hline & Neutral & 10 & 12 & 8 \\
\hline & Disagree & 6 & 24 & 15 \\
\hline & Strongly Disagree & 3 & 40 & 8 \\
\hline & No opinion & 0 & 0 & 15 \\
\hline \multirow{6}{*}{$\begin{array}{l}\text { (2) Evidence led by the } \\
\text { defense }\end{array}$} & Strongly Agree & 3 & 8 & 8 \\
\hline & Agree & 29 & 42 & 23 \\
\hline & Neutral & 29 & 37.5 & 15 \\
\hline & Disagree & 19 & 4 & 15 \\
\hline & Strongly Disagree & 3 & 8 & 8 \\
\hline & No opinion & 16 & 0 & 31 \\
\hline
\end{tabular}

Figure 12 
The responses revealed a profound yet asymmetrical disagreement along partisan lines. Question 1 (concerning evidence led by the prosecution) elicited the most extreme divergence of any question in the survey. In response to Question 2 (evidence led by the defense), far more defense respondents agreed than disagreed, but prosecution respondents as well tended to agree (albeit by a smaller margin) that defense experts had contributed insights into IHL violations. Speculatively, this asymmetry could reflect a belief on the part of some prosecution respondents that bias displayed by defense experts from the former Yugoslavia may occasionally reveal a state of mind or historical narrative prevalent in the region in line with prosecution contentions.

This concern is related to the issue addressed in two further questions, concerning "the degree to which contextual expert witnesses called by the prosecution (a)/defense (b) have been appropriately prepared for testimony in the courtroom." These questions address broader perceptions regarding how adequate the experts for the parties have been. This issue, in turn, arises out of two primary concerns. The first involves relative access to resources, including the best experts available, due to financial, staffing or time restrictions, or possibly to fear of stigmatization from appearing for one or the other party. Defense teams have, on multiple occasions, protested a lack of "equality of arms" vis-à-vis the prosecution in these respects, while prosecution teams have also encountered difficulty in identifying and engaging qualified experts. The second concern has to with experts' understanding of their role in the process (e.g., neutral vs. partisan; to answer questions vs. expounding upon a topic; required documentation). 
The degree to which contextual expert witnesses called by the prosecution have been appropriately prepared for testimony in the courtroom

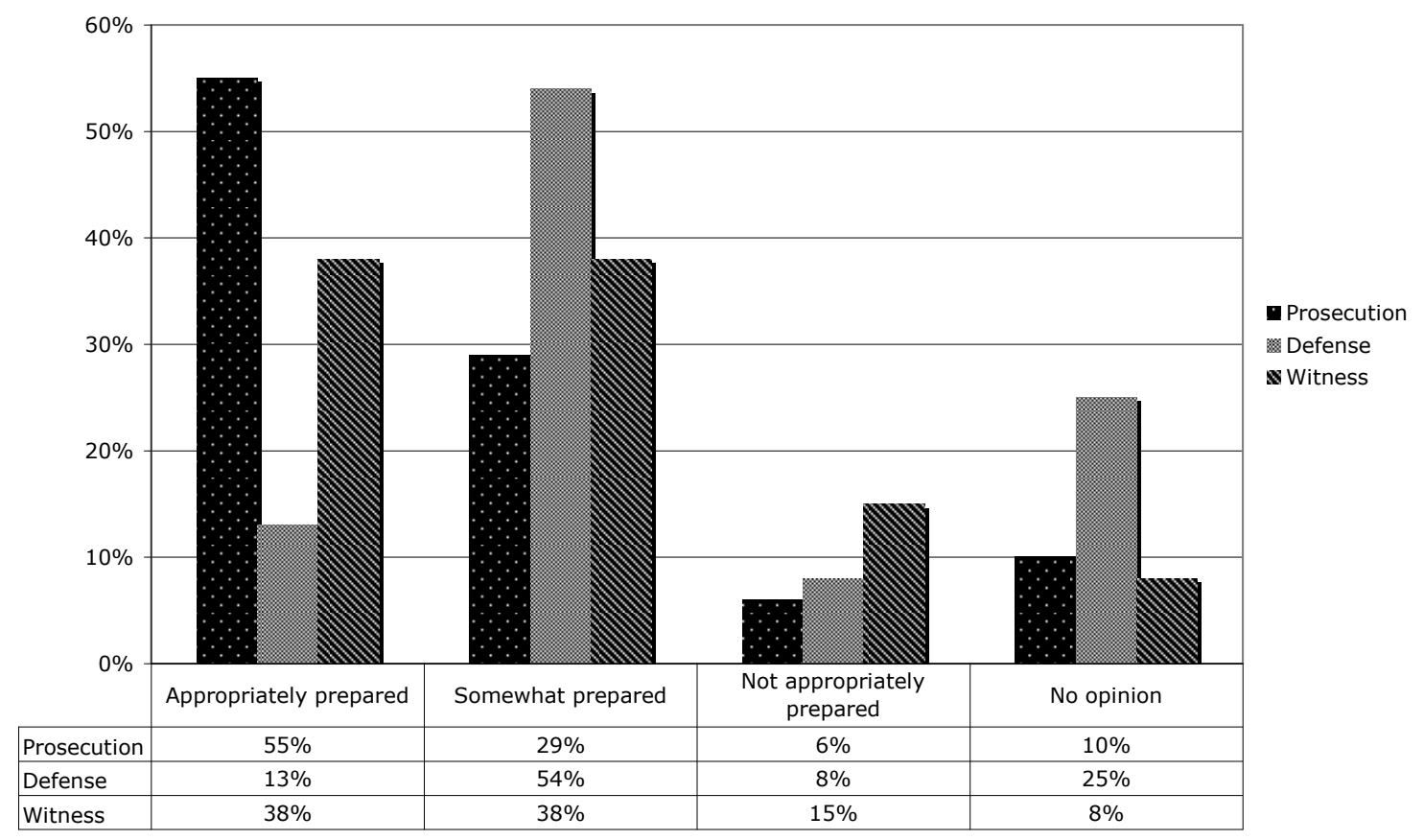

Figure 13(a) 
The degree to which contextual expert witnesses called by the defense have been appropriately prepared for testimony in the courtroom

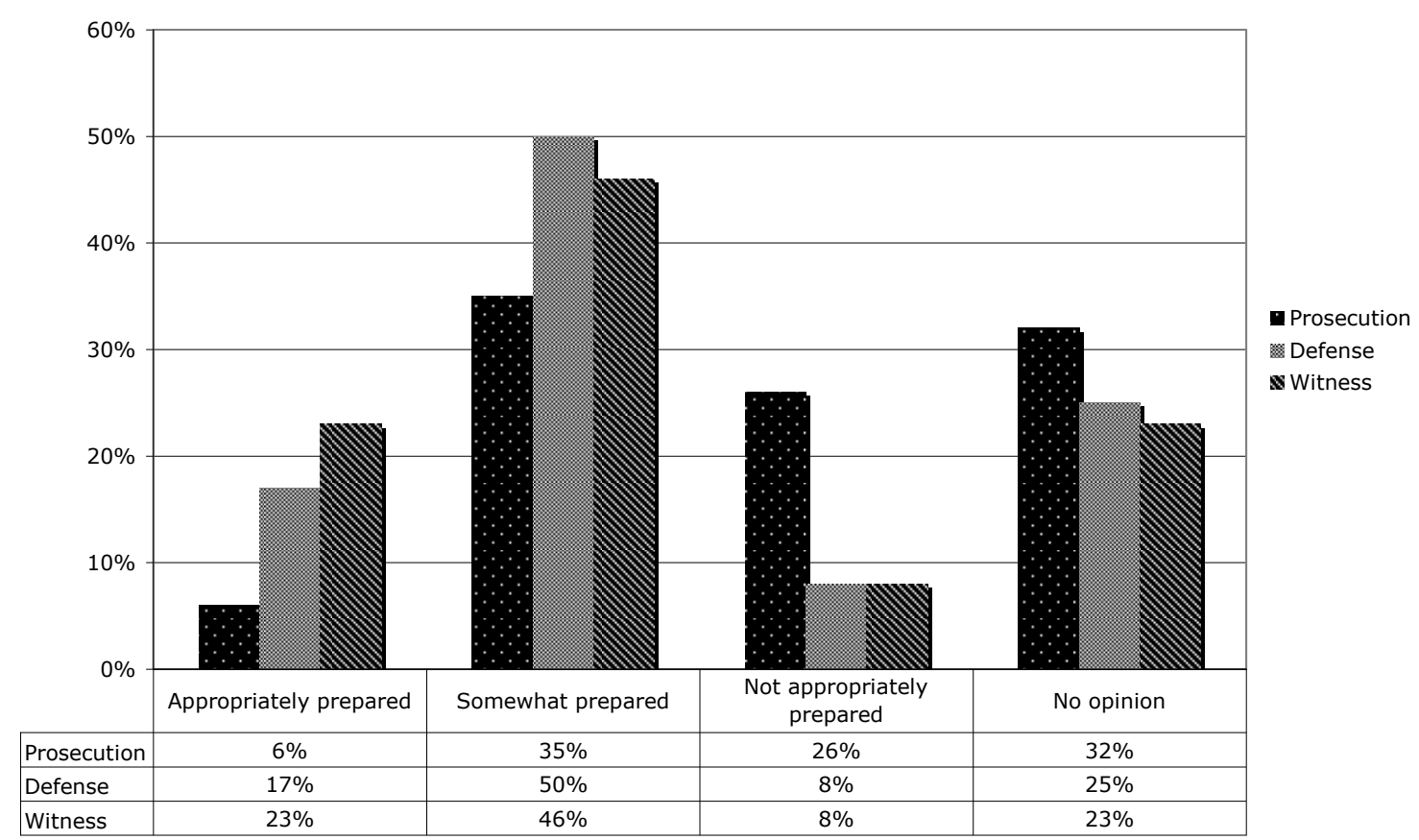

Figure 13(b)

Prosecution and defense respondents differed asymmetrically on this issue. Most strikingly, while a majority of prosecution respondents felt that prosecution experts had been "appropriately prepared," only $17 \%$ of defense respondents believed that their own experts had been "appropriately prepared." This may reflect the concern of defense respondents regarding equality of arms at the ICTY. Most of those defense and prosecution respondents who were willing to offer an opinion about the preparation of experts for the other side acknowledged that those experts were at least "somewhat prepared," although a larger proportion of prosecution respondents considered defense experts "not appropriately prepared." This asymmetry may be interpreted as a form of prosecution concurrence with defense respondents' reluctance to consider defense experts as having been "appropriately prepared."

Three questions evaluated the effectiveness of expertise in terms of its reception by the trial chambers. Two of these questions, "How receptive are ICTY judges to the 
testimony of historians serving as expert witnesses called by the defense (a)/prosecution (b)?," elicited a striking pattern of asymmetrical differences between defense and prosecution respondents.

\begin{tabular}{|c|c|c|c|c|}
\hline & & Pros.\% & Defense\% & Witness\% \\
\hline \multirow{5}{*}{$\begin{array}{l}\text { A) Receptivity of ICTY judges } \\
\text { to defense expert witnesses }\end{array}$} & Highly Receptive & 0 & 0 & 15 \\
\hline & $\begin{array}{l}\text { Somewhat } \\
\text { Receptive }\end{array}$ & 61 & 50 & 46 \\
\hline & Unreceptive & 6 & 21 & 8 \\
\hline & $\begin{array}{l}\text { Highly } \\
\text { Unreceptive }\end{array}$ & 0 & 21 & 0 \\
\hline & No opinion & 32 & 8 & 31 \\
\hline \multirow{5}{*}{$\begin{array}{l}\text { B) Receptivity of ICTY judges } \\
\text { to prosecution expert } \\
\text { witnesses }\end{array}$} & Highly Receptive & 10 & 33 & 23 \\
\hline & $\begin{array}{l}\text { Somewhat } \\
\text { Receptive }\end{array}$ & 71 & 50 & 54 \\
\hline & Unreceptive & 0 & 8 & 0 \\
\hline & $\begin{array}{l}\text { Highly } \\
\text { Unreceptive }\end{array}$ & 0 & 0 & 0 \\
\hline & No opinion & 19 & 8 & 23 \\
\hline
\end{tabular}

Figure 14

No respondent from the prosecution or defense acknowledged that judges were highly receptive to defense experts. Remarkably, defense respondents were more likely than prosecution respondents to consider judges "Unreceptive" or "Highly Unreceptive" to defense experts. This confirms defense responses indicating that, generally, their experts were not as adequately prepared as prosecution experts, which, in turn, follows from the defense perception of an "inequality of arms" in the ICTY's proceedings. These impressions are strengthened by responses concerning judges' receptivity to 
prosecution witnesses. Defense respondents tended to agree with prosecution respondents that judges were "Somewhat Receptive" or "Highly Receptive" to prosecution expertise.

The sense that defense respondents perceive an overall bias on the part of the Court and less adequate preparation of their side's expert witnesses is further supported by responses to a further question: "When the historian expert witnesses of the prosecution and defense contradict one another, how do judges decide between their competing historical accounts?"

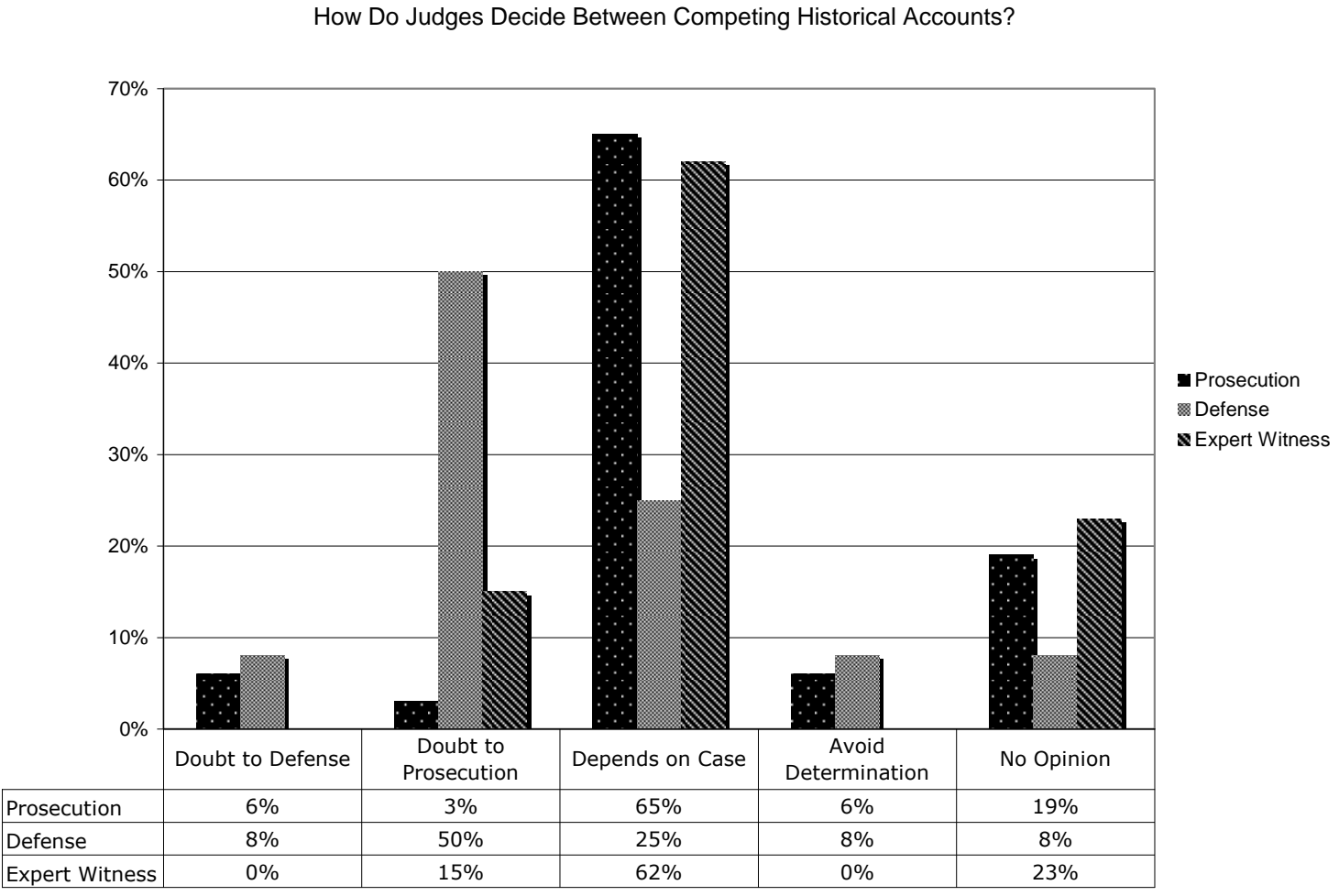

Figure 15

This question elicited striking disagreement between prosecution and expert respondents, on the one hand, and defense respondents, on the other. By a wide margin, the former felt that this depended on the case. However, half of the defense respondents (a majority of those who offered an opinion) believed that judges generally give the doubt to the prosecution. 
Two questions in True-False format considered speculation regarding motives of the prosecution and defense in introducing historical evidence to meet perceived weaknesses in their cases:

\begin{tabular}{|l|l|r|r|r|}
\hline \multicolumn{2}{|c}{} & Pros.\% & Defence\% & Witness\% \\
\hline A) Prosecutors lead historical & True & 10 & 46 & 23 \\
\cline { 2 - 5 } $\begin{array}{l}\text { evidence when their material } \\
\text { evidence [e.g., forensics, } \\
\text { documents] is weak }\end{array}$ & False & 68 & 21 & 38 \\
\cline { 2 - 5 } & No Opinion & 23 & 33 & 38 \\
\hline $\begin{array}{l}\text { B) The defense calls } \\
\text { historians as expert witnesses } \\
\text { in order to mount a tu quoque } \\
\text { defense }\end{array}$ & False & 48 & 17 & 23 \\
\cline { 2 - 5 } & No Opinion & 13 & 42 & 23 \\
\hline
\end{tabular}

Figure 16

While we expected the survey to dispel the impression that such views might be widespread, it suggested in fact that each is entrenched within one party to the process, and that the parties are in striking disagreement with one another in these regards.

A further series of questions addressed additional perspectives bearing on the effectiveness of modes of introducing expert evidence.

\footnotetext{
${ }^{20}$ As defined at the ICTY, "The defence of tu quoque concerns the allegation that the opposing party to the conflict committed similar atrocities" and/or "the allegation that that party was responsible for the commencement of the said conflict" ("Decision on Evidence of the Good Character of the Accused and the Defence of Tu Quoque," The Prosecutor v. Zoran Kupreskić et al., IT-95-16-T, 17 February 1999). The admissibility of a tu quoque defense has been generally denied in international criminal law since Nuremberg.
} 
One asked whether internal OTP staff experts or external experts have been more effective.

Which have been more effective as expert witnesses in the Trial Chamber?

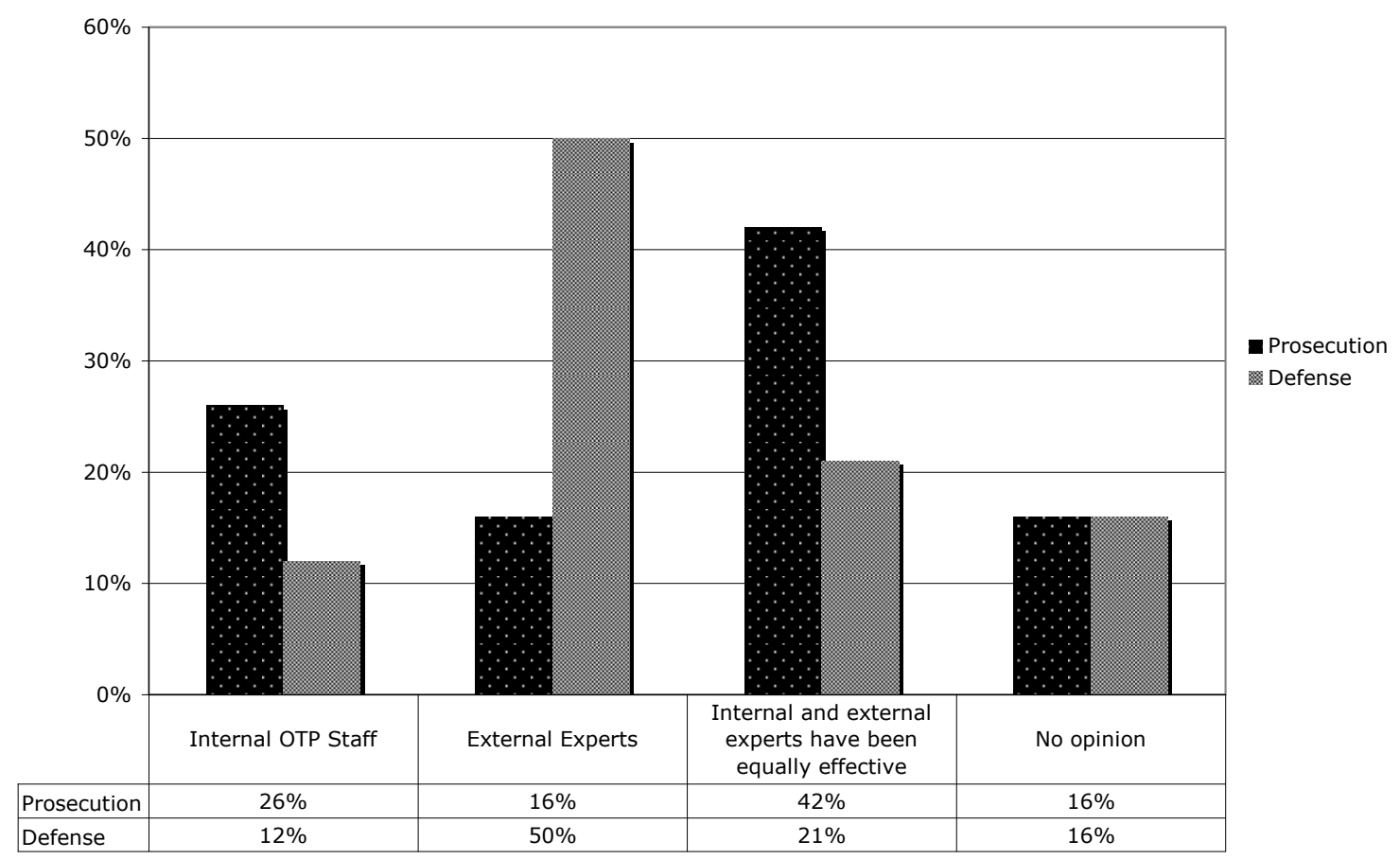

Figure 17

While a plurality of prosecution respondents considered internal and external experts equally effective, half of defense respondents believed that external experts were more effective, and few acknowledged internal experts to be more effective. It is possible that some defense respondents used this question as a surrogate for another un-posed question which, in retrospect, should therefore have been included: whether it is appropriate, in terms of fairness and objectivity, for OTP staff members to appear as expert background witnesses. Some defense attorneys have argued strenuously against this practice, including President of the ICTY Defense Attorneys' Association, Michael G. Karnavas: "I have objected to calling expert witnesses from the OTP. They are not independent, but have been part of the prosecution team for years. They are not going to jeopardize their position by going against the case an STA is trying to build. These prosecution analysts-turned-experts are usually engaged in the stages of drafting the 
indictment, gathering the evidence, and presenting evidence. Their reports mirror the prosecution theory as reflected in the indictment, and one can hardly claim these reports to be objective." ${ }^{21}$

A second question asked which has greater significance for the outcome of a trial: expert testimony led in the Trial Chamber or expert reports submitted to the Trial Chamber. On this question, which does not go to issues that might be considered contentious among the parties, all categories of respondent were in essential accord, with a majority believing live testimony to have a greater impact. While reports, with their associated documentation, gave the Trial Chambers the ability to analyze experts' positions, underlying arguments and documentation in greater detail and depth, and to prepare carefully for oral questioning of experts, respondents nevertheless felt that in the end it was the oral testimony of the experts that carried the greatest weight.

A final question addressed one of the most important aspects of the ICTY's legacy for the region of conflict: "Have historical discussions at the ICTY enhanced or undermined the Tribunal's legitimacy in the former Yugoslavia?" The results revealed a profound difference of perception, with prosecution and defense responses almost diametrically opposed. While a plurality of prosecution respondents (42\%) believed the ICTY's legitimacy to have been enhanced by historical discussions at the ICTY, a majority of defense respondents (62.5\%) believed that the ICTY's legitimacy had been undermined by this discussion. The smaller number of expert responses was almost evenly divided. Most prosecution staff members are from outside the region of the former Yugoslavia while a significant number of defense team members are from within the region; it remains beyond the scope of the present investigation, however, to determine which position is in better accord with public opinion in the various regions of the former Yugoslavia.

\footnotetext{
${ }^{21}$ Author interview (Richard Wilson), June 2007.
} 
Many respondents availed themselves of the opportunity to add comments, some brief, others extensive, in the text field provided at the conclusion of the survey. We cannot capture the full scope and richness of those qualitative comments here, but will note several of the issues that were brought to our attention, including some leitmotifs.

Beginning from the more critical comments, some respondents believe the use of historical experts to be entirely inappropriate. One response tied the utilization of historical expertise to a flawed prosecution strategy of investigations and prosecutions. Instead of taking a pragmatic approach, gathering sufficient evidence to convict perpetrators in a rapid and cost effective manner, over-expansive investigations and allencompassing indictments have led to excessively long investigations and trials. Another asserted that insufficient time has elapsed since the events for an objective, comprehensive and balanced historical account to be compiled.

One recurring perception was that historical expertise has skewed the historical record through intentional or inadvertent bias. On the one hand, two respondents speculated that the methodology, conceptual framework (e.g., concept of "nation") or area of interest/specialization of a particular expert may have distorted the results. On the other hand, multiple respondents expressed the view that expert witnesses typically favored one side or the other, or were chosen to espouse a favored point of view. According to two respondents, the favored view within the Office of the Prosecutor might change from one case to the next depending on the ethnic group of the accused, while one perceived courtroom historical expertise as having become a continuation of the military conflict by other means. According to one, such effects could be viewed as one result of the prosecution strategy of targeting investigation/trial teams for particular "perpetrator groups," rather than for the events of a particular region. Another asserted that had the prosecution more effectively employed its in-house expertise on the former Yugoslavia and centralized that expertise in the investigative 
and trial preparation process, a more coherent prosecution position on the history of the conflicts would have been achieved. Yet another suggested that it might have been preferable to engage experts not by the two sides, but in a role similar to an amicus curiae. Finally, one respondent noted the inherent limitation on the ability of judges to evaluate expert evidence, and of lawyers to evaluate and exploit such evidence, noting that both judges and lawyers will prefer simpler solutions, while the latter will favor versions that support their particular case.

Multiple comments from respondents who participated for the defense contained explicit claims of institutional bias relevant to expertise, including claims that there was no equality of arms, a de facto burden of proof on the defense, and that judges gave the benefit of the doubt to prosecution experts. One respondent claimed that an accusatorial climate, created and fostered by the prosecution in the former Yugoslavia, had chilled the willingness of qualified witnesses to present a historical narrative at odds with the prosecution's. One defense attorney asserted that the Court's decision to accept hearsay evidence and to basically ignore obvious perjury set the stage for a system that could not produce an accurate history of the events and was not likely produce justice either.

In contrast to the largely negative perceptions expressed above, a smaller number of remarks, in some cases by the same respondents who voiced critical comments, affirmed the value of historical (broadly defined) expertise for the success of the ICTY's efforts. Inter alia, one noted that the employment of expert witnesses has allowed for a large body of previously unavailable documentation to be revealed, studied and analyzed by experts called by the prosecution and defense for the purpose of these trials. This person added that the use made of this body of evidence by future historians may eventually lead to a fuller understanding of these events than one could reasonably expect from the expert presentations prepared within the context (and limitations) of specific cases before the ICTY. Another noted that the employment of experts allowed 
for the inclusion of relevant evidence from outside the former Yugoslavia, e.g., parallel examples of the use of mass media to spread falsehoods, so as to provide a perspective for better understanding similar events in the Balkans.

We had expected to receive comments asserting the value of expert witnesses in educating judges who had no previous experience with events in the former Yugoslavia and the history of the region. However, as cited above, the one comment that touched upon this topic asserted that, despite such testimony, some judges and lawyers appeared to have an incomplete grasp of basic facts and background information even after serving on more than one case at the ICTY; although the evidence of experts can be of assistance in remedying this inherent weakness, it can be difficult for the judges to sort out conflicting claims by expert witnesses called by the two sides. Another respondent, echoing this same theme, stated that different trial chambers during simultaneous trials might reach differing and often opposing conclusions.

\section{Correlation Analysis}

We ran correlation tests on our data to determine whether there were any correlations between the responses and 1) the length of service at the ICTY; 2) prior knowledge of the former Yugoslavia; and 3) prior experience of a criminal justice system. Given the non-parametric nature of our data, we ran a Spearman correlation test to examine the relationship between the time of service at the ICTY variable and the rest of the issues raised in the survey. ${ }^{22}$

\footnotetext{
${ }^{22}$ In a Spearman test, an ideal +1 or -1 correlation occurs when each of the variables is a perfect monotone function of the others. A positive correlation occurs when the significance value is smaller than +.05 , and a negative correlation occurs when the significant value is smaller than -
} .05 . 
While the formal tests resulted in no significant value for the overall survey, the following chart that calculates the mean of each question visualizes some disparities among the groups based on the length of time they served. In other words, it illustrates the relationship between participants' responses to questions in relation to their length of association with the ICTY. Although Figure 18 aggregates information and tells us little about the overall survey, the most significant aspect here is the variation in some responses depending on length of association with the Tribunal. We divided the length of association into four categories: 1 ) those who worked less than one year; 2 ) those who worked from 1 to 2 years; 3 ) those who worked from 2 to 5 years; and finally 4) those who worked for more than 5 years. The numbers on the $X$ axis refer to issues raised in the survey (i.e., each question in the survey) while the numbers on the $\mathrm{Y}$ axis indicate the variation in opinions expressed. The y axis values range between 1 and 5; that is, from "strongly agree" to "no opinion." The same process was applied to Figure 19 , but it included what we considered to be the most controversial questions.

The divide is wider and more obvious between the two groups with the least amount of service ("less than 1 year" and "1-2 years" of association) compared with the other two groups who served longer ("2-5 years" and "more than 5 years" of association). In other words, it does suggest a variation in their responses based on the time variable; however, the level of significance varies depending on which groups are being compared. Those who worked longer, for example, from 2 to 5 years or longer, generally show more agreement upon issues presented in the survey. Major disagreements remain between the groups with less than 2 years of service and groups with 2 or more years' involvement. 


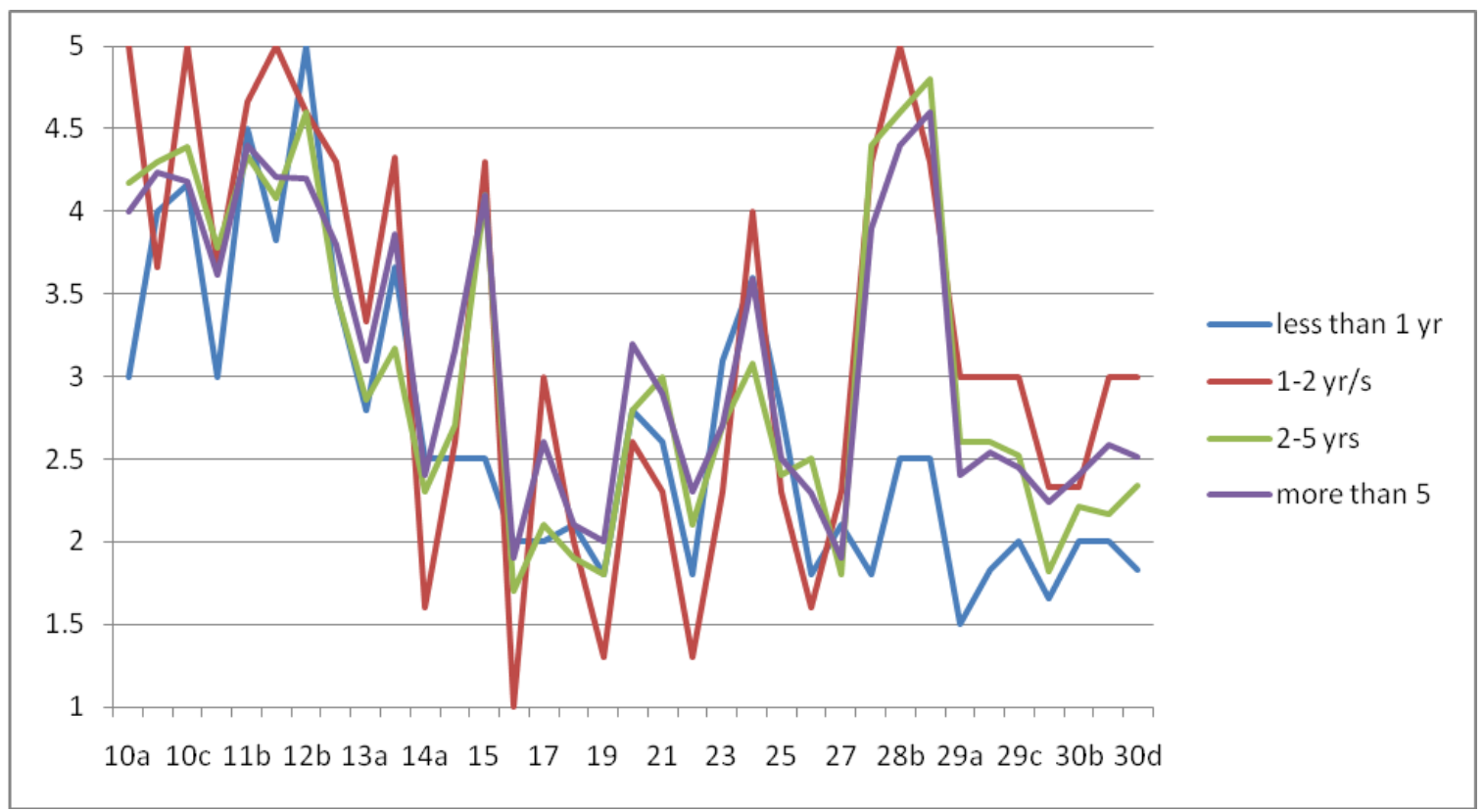

Figure 18: Responses to All Questions Nos. 10-30

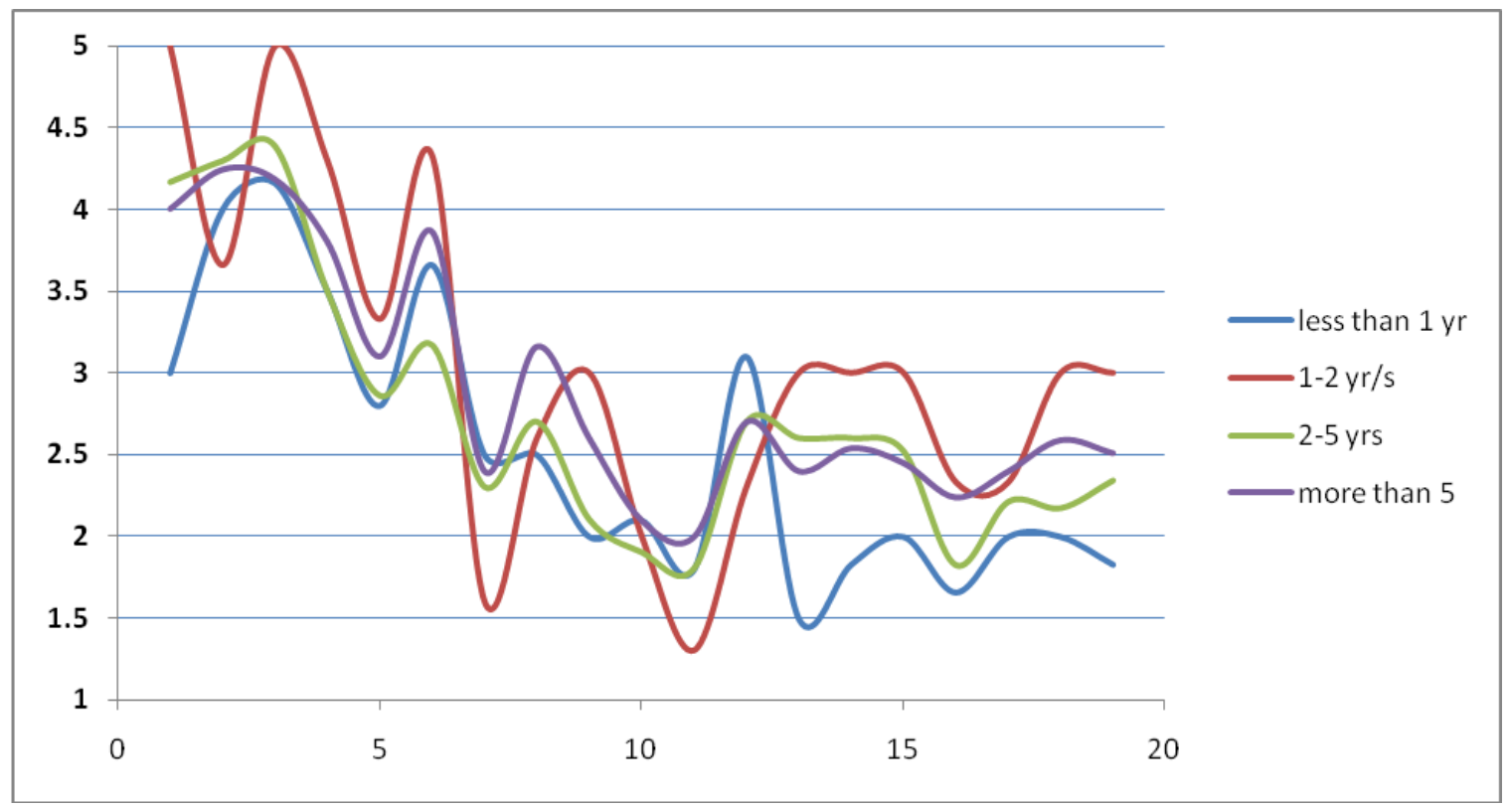

Figure 19: Responses to Selected Questions

Correlation tests were repeated with the other two variables (prior knowledge of the former Yugoslavia; and prior experience of a criminal justice system) and the results did not show any statistically significant correlations. While these tests show no correlations, they do still indicate something of value - that the replies of individuals 
with little experience of a criminal justice system or the former Yugoslavia do not differ considerably from those of more experienced individuals. However, participants' views do seem to change substantially by virtue of exposure to the ICTY's work over time, suggesting that socialization in the norms and conventional views of the ICTY is a more determining factor in changing opinion than prior experience of legal institutions or the region.

VI. Conclusions

In contrast to Hannah Arendt's (1965:91) austere legal minimalism where history is deemed not legally relevant, the parties to ICTY trials do have clear legal motivations to include historical evidence; that is, they include this type of evidence because it allows them to achieve certain legal objectives in the trial. On these issues, there was much more consensus between prosecution and defense respondents than on questions eliciting evaluation of the outcome of the Tribunal's historical forays. In part, this could be because the parties share some legal objectives and institutional conditions. The rules of admissibility of evidence in international criminal tribunals grant both parties similar latitude in developing their cases. Both parties appear before international judges who, at least in the beginning, require historical and cultural contextualization to make sense of the evidence. Prosecutors and defense attorneys perceive the actual crimes similarly (as "widespread and systematic", as "complex") and accept the same categorical imperative to use historical evidence. This consensus on the repercussions of the crimes for the legal process continues when the questions turn to the legal conceptions of international criminal law itself. There is strong agreement that the collective dimension of crimes against humanity affects the use of historical evidence.

Despite these areas of agreement, however, historical evidence clearly assumes a distinct legal relevance for each party in the adversarial process. This is perhaps to be expected, as Marc Galanter (1974:97) described some time ago the different legal 
strategies adopted by "one-shotters" and "repeat players" as they played the "litigation game." ${ }^{23}$ At the ICTY, prosecutors are more likely to occupy the "repeat player" end of the continuum, taking advantage of the benefits that accrue (e.g., expertise, advance intelligence etc). Prosecutors are using historical evidence to build their theory of a case and to demonstrate the criminal intention of the accused, especially in cases where they must prove special intent to commit genocide. In qualitative interviews conducted before this survey, it became apparent that some prosecutors saw in historical evidence the opportunity to demonstrate how a nationalist ideology (e.g., Greater Croatia, Greater Serbia) engendered an enduring desire to hold a particular territory or subordinate another ethnic/national group within a state or territory.

The fact that a majority of defense counsel were willing to subscribe to the potential link between history, mental state and genocide invites further discussion, since this would appear to be against their clients' interests. Certainly, history is of greater intrinsic concern to the accused than the prosecutors, and historical treatises in the courtroom seem to play well with an audience back in the region (Tosić 2007). Perhaps defense attorneys perceive an opportunity to support a "chaos defense," or, conversely, to undercut prosecution arguments that there was a long-standing desire on the part of nationalists to commit genocide. Or perhaps, given that sentencing and judgment occur simultaneously at the ICTY, they see an opportunity to demonstrate how any attacks constituted justifiable reprisals in response to past provocations. Presenting the history of nationalist ideology in the former Yugoslavia, then, may assist the prosecution and the defense cases, albeit in different ways. It helps prosecutors develop their case theory and elaborate their narrative on genocidal intent, but it also allows defense to lead evidence that may sew uncertainty regarding issues of ideology and superior responsibility.

\footnotetext{
${ }^{23}$ We thank an anonymous reviewer for pointing out the relevance of Galanter's ideas to interpreting the survey results.
} 
Turning now to responses that assess the historical accounts produced or presented at the ICTY, and their reception both at the ICTY and in the former Yugoslavia, one striking generalization stands out. On questions that concern the fairness/objectivity of the ICTY's process, judges' receptivity to evidence, and the accuracy, objectivity and comprehensiveness of the historical accounts created at the ICTY, prosecution and defense responses diverged widely. .

If the broader "chapeau" goals of the ICTY have been to promote reconciliation in the former Yugoslavia and deter future conflict by providing accountability that is perceived in the region to be fair and objective, and which is so well documented that it will be resistant to later revisionism, then the results of this survey do not bear out these wider goals. While parties to an adversarial process must vigorously advocate their respective positions in individual cases, for these goals to be achieved, then the parties must approach, at least gradually, a common understanding on issues relating to effectiveness and fairness of the process itself. Yet, this survey suggests that over more than 15 years of ICTY practice, at least in matters related to historical inquiry, the parties have not achieved such a common ground which could form a strong basis for acceptance of the Tribunal's work in the regions of conflict. If we speculate that those views which are preponderant among defense respondents reflect opinions that are widespread in the former Yugoslavia, then we must conclude the Tribunal's legacy in that region, at least in regard to the historical record that it has created, will not be a salient one. We must also conclude that the ICTY's international legacy as a pioneering institution of international justice will be diminished at least in this regard.

Ultimately, the multifarious historical accounts created within the framework of the ICTY will be available for evaluation by future generations of researchers, and will not stand or fall on the basis of assessments by the immediate participants in the trials. The ICTY's contribution to historical inquiry into the recent conflicts, moreover, will be but one of many. As articulated by one expert witness: 
"The process of international criminal justice at the ICTY, and the testimony and evidence that it has produced has added significantly to the available historical evidence concerning events in the former Yugoslavia during the final decades of the 20th century. The use made of this body of evidence by future historians may eventually lead to a fuller understanding of the critical questions about these events than one could reasonably expect from the expert presentations prepared within the context (and limitations) of specific cases before the court."

Reviewing the results of the survey, we see some clear implications for the extant literature on the ICTY's ability to facilitate reconciliation among the population of the former Yugoslavia and Bosnia and Herzegovina in particular. The edited volume by Stover and Weinstein (2004) offers a number of examples (e.g., Mostar and Prijedor in Bosnia and Vukovar in Croatia) in support of its contention that international trials have little impact on reconciliation and social reconstruction. Subotić (2009:6) finds evidence to support these claims in her elucidation of how political actors in Bosnia, Croatia and Serbia often hijack the ICTY's work for their own domestic agenda, thus jeopardizing the legitimacy and effectiveness of the international justice institution. ${ }^{24}$ Kostić (2007:355) concludes that "in the case of persisting group insecurities and ethnonational mobilization, different ethnonational communities, instead of wholeheartedly embracing justice and truth from international or hybrid tribunals, are more likely to view them selectively and on the basis of their particular definition of war, defenders and perpetrators." From this perspective, the expectation that the ICTY can promote reconciliation, at least in the near term, by establishing an accurate historical account that is acceptable to all and resistant to revisionism may itself be misplaced.

\footnotetext{
${ }^{24}$ See also Klarin (2009) which also assesses the ICTY's Outreach Program.
} 
Our research shows that the international criminal proceedings, based as they are in the adversarial process, may enhance an oppositional mentality, polarize historical accounts further and widen the chasm rather than construct a common bridge between populations. However, we note more recent attitudinal research in Bosnia by Nettelfield (2010) challenging the emerging negative consensus. Lara Nettelfield claims that previous scholars have overlooked the ways in which the ICTY has promoted democratization and, if not exactly "reconciliation", then at least the internalization of basic human rights norms, by creating new post-war political identities based on the rule of law and participation (p.15). Our view is that these questions are temporally defined, and the impact of the ICTY on reconciliation, rule of law and historical denial in the former Yugoslavia cannot be fully known until some years after its work is complete. We would observe at this point that the fact that the actual legal proceedings at the ICTY seem to push the actors further apart on central historical issues does not bode well for the ICTY's legacy.

Nevertheless, the contribution of the ICTY is unique and non-replicable in its methodology, access to information, and in the nature of its products. It is also distinctive in its potential to positively or negatively affect reconciliation and historical debate in the public spaces in the regions of conflict. It is for both of these reasons that we have attempted to contribute to the project of assessing its successes and failures. 


\section{References}

Arendt, Hannah. 1965. (1963). Eichmann in Jerusalem: a report on the banality of evil. Revised and Enlarged edition. NY: Viking Press.

Bloxham, Donald. 2001. Genocide on Trial: War Crimes Trials and the Formation of Holocaust History and Memory. Oxford: Oxford University Press.

Cassese, Antonio. 2003. International Criminal Law. Oxford: Oxford University Press.

Clarke, Kamari. 2009. Fictions of Justice: The International Criminal Court and the Challenge of Legal Pluralism in Sub-Saharan Africa. New York: Cambridge University Press.

Del Ponte, Carla. 2009. Madam Prosecutor: Confrontations with Humanity's Worst Criminals and the Culture of Impunity: a memoir. With Chuck Sudetic. New York: Other Press.

Donia, Robert. 2004. 'Encountering the Past: History at the Yugoslav War Crimes Tribunal.' The Journal of the International Institute: University of Michigan. WinterSpring/Summer. Pp. 1-2, 15.

Douglas, Lawrence. 2001. The memory of judgment: making law and history in the trials of the Holocaust. New Haven: Yale University Press.

Dörmann, Knut. 2003. Elements of War Crimes Under the Rome Statute of the International Criminal Court: sources and commentary. Cambridge: Cambridge University Press. 
Evans, Richard J. 2002. "History, Memory and the Law: the Historian and Expert Witness." History and Theory. 41(3): 326-345.

Galanter, Marc. 1974. "Why the 'Haves' Come Out Ahead: Speculations on the Limits of Legal Change." Law and Society Review. Vol. 9, pp. 95-160.

Geertz, Clifford 1983. 'Fact and Law in Comparative Perspective'. In Local Knowledge: Further essays in interpretative anthropology. New York: Basic Books.

Goldstone, Richard. 2000. For Humanity: Reflections of a War Crimes Investigator. New Haven, Conn.: Yale University Press.

Golsan, Richard J. 2000. 'History and the "Duty to Memory" in Postwar France: the pitfalls of an ethic of remembrance.' In Howard Marchitello, ed., What Happens to History: the renewal of ethics in contemporary thought. New York: Routledge.

Greenwalt, Alexander. 1999. 'Rethinking Genocidal Intent: the case for a knowledgebased interpretation'. Columbia Law Review. Vol. 99, No. 8, pp. 2259-2294.

Hagan, John. 2003. Justice in the Balkans: Prosecuting War Crimes in the Hague Tribunal. Chicago: University of Chicago Press.

Hayden, Robert M. 2008. "'Genocide Denial' Laws as Secular Heresy: A Critical Analysis with Reference to Bosnia." Slavic Review. 67(2): 384-407.

Hazan, Pierre. 2004. Justice in a Time of War: The True Story Behind the International Criminal Tribunal for the Former Yugoslavia. Translated by James Thomas Snyder. College Station: Texas A\&M Press. 
Kostić, Roland. 2007. Ambivalent Peace: External Peacebuilding, Threatened Identity and Reconciliation in Bosnia and Herzegovina. Uppsala Universitet: Department of Peace and Conflict Research, Report No. 78.

Klarin, Mirko. 2009. "The Impact of the ICTY Trials on Public Opinion in the former Yugoslavia." Journal of International Criminal Justice. 7(1): 89-96.

Langer, Máximo. 2005. "The Rise of Managerial Judging in International Criminal Law." American Journal of Comparative Law, Vol. 53, No. 4 (Fall, 2005), pp. 835-909.

Moghalu, Kingsley Chiedu. 2008. Global Justice: the politics of war crimes tribunals. Stanford: Stanford University Press.

Marrus, Michael. 1997. Nuremberg War Crimes Trial of 1945-6. Boston, Mass: Bedford Press.

Meierhenrich, Jens. 2008. Review of The UN International Criminal Tribunals by William Schabas. American Journal of International Law. Vol. 102, No. 3, July, pp. 696-703.

Mertus, J. 2000. 'Truth in a Box: the limits of justice through judicial mechanisms.' Pp. 142-161. In Ifi Amadiume and Abdullahi A An-Na'im, eds., The Politics of Memory: Truth, Healing and Social Justice. London: Zed Books.

Minow, Martha. 1998. Between Vengeance and Forgiveness: facing history after genocide and mass violence. Boston, Mass.: Beacon Press.

Mundis, Daryl. 2001. 'From "Common Law" Towards "Civil Law": the evolution of the ICTY rules of procedure and evidence. Leiden Journal of International Law. 14:367-382. 
Nettelfield, Lara. 2010. Courting Democracy: The Hague Tribunal's Impact in BosniaHerzegovina. Cambridge: Cambridge University Press.

Osiel, Mark. 2000. (1997). Mass Atrocity, Collective Memory and the Law. New Brunswick, NJ.: Transaction. Paperback version.

Peskin, Victor. 2008. International Justice in Rwanda and the Balkans: virtual trials and the struggle for state cooperation. Cambridge: Cambridge University Press.

Rousso, Henry. 1997. "Letter to the President of the Bordeaux Assizes Court." 6 October 1997. In Golsan, Richard J., ed., 2000. The Papon Affair: memory and justice on trial. New York: Routledge. Pp. 193-4.

Sadkovich, James J. 2002. "Argument, Persuasion and Anecdote: the usefulness of history to understanding conflict." Polemos. 1-2:33-49.

Schabas, William. 2001. An Introduction to the International Criminal Court. Cambridge: Cambridge University Press. . 2009. Genocide in International Law: The Crime of Crimes. Cambridge: Cambridge University Press. Second Edition.

Stover, Eric. 2005. The Witnesses: War Crimes and the Promise of Justice in The Hague. Philadelphia: University of Pennsylvania Press.

Stover, Eric and Harvey Weinstein. 2004. My Neighbor, My Enemy: justice and community in the aftermath of mass atrocity. Cambridge: Cambridge University Press.

Subotić, Jelena. 2009. Hijacked Justice: Dealing with the Past in the Balkans. Ithaca, NY: Cornell University Press. 
Todorov, Tzvetan. 1996. 'The Touvier Affair' R.J. Golsan, ed., Memory, the Holocaust and French Justice: the Bousquet and Touvier Affairs. Dartmouth: University Press of New England. Pp. 114-121.

Tosić, Jelena. 2007. “Transparent Broadcast? The Reception of Milošević's Trial in Serbia." in M. Dembour and T. Kelly, eds., Paths to International Justice: Social and Legal Perspectives. Cambridge: Cambridge University Press.

Turković, Ksenija. 2003. "Historians in Search for Truth about Conflicts in the Territory of Former Yugoslavia as Expert Witnesses in front of the ICTY." Journal of Contemporary History (Zagreb). Vol. 36, No. 1: pp. 41-67.

Wald, Patricia. 2001. 'To "Establish Incredible Events by Credible Evidence" The Use of Affidavit Testimony in Yugoslav War Crimes Tribunal Proceedings.' 24 Harvard International Law Journal. 42(2): 535-553. 